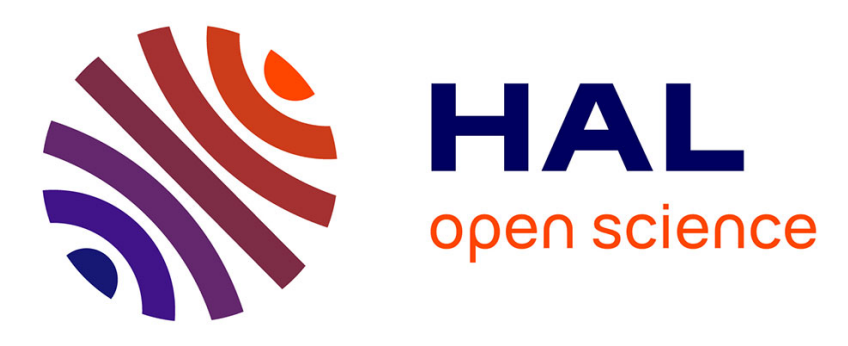

\title{
Development and refinement of proxy-climate indicators from peats
}

Frank M. Chambers, Robert K. Booth, François de Vleeschouwer, Mariusz

Lamentowicz, Gaël Le Roux, Dmitri Mauquoy, Jonathan E. Nichols, Bas van

Geel

\section{To cite this version:}

Frank M. Chambers, Robert K. Booth, François de Vleeschouwer, Mariusz Lamentowicz, Gaël Le Roux, et al.. Development and refinement of proxy-climate indicators from peats. Quaternary International, 2012, vol. 268, pp. 21-33. 10.1016/j.quaint.2011.04.039 . hal-00980256

\section{HAL Id: hal-00980256 https://hal.science/hal-00980256}

Submitted on 17 Apr 2014

HAL is a multi-disciplinary open access archive for the deposit and dissemination of scientific research documents, whether they are published or not. The documents may come from teaching and research institutions in France or abroad, or from public or private research centers.
L'archive ouverte pluridisciplinaire HAL, est destinée au dépôt et à la diffusion de documents scientifiques de niveau recherche, publiés ou non, émanant des établissements d'enseignement et de recherche français ou étrangers, des laboratoires publics ou privés. 


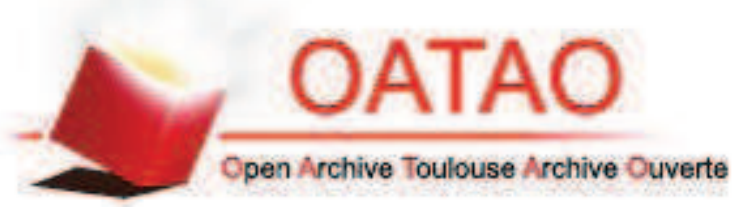

\section{Open Archive TOULOUSE Archive Ouverte (OATAO)}

OATAO is an open access repository that collects the work of Toulouse researchers and makes it freely available over the web where possible.

This is an author-deposited version published in : http://oatao.univ-toulouse.fr/ Eprints ID : 11364

To link to this article : DOI: 10.1016/j.quaint.2011.04.039

http://dx.doi.org/10.1016/j.quaint.2011.04.039

To cite this version Chambers, Frank M. and Booth, Robert $K$. and De Vleeschouwer, François and Lamentowicz, Mariusz and Le Roux, Gaël and Mauquoy, Dmitri and Nichols, Jonathan E. and van Geel, Bas Development and refinement of proxy-climate indicators from peats. (2012) Quaternary International, vol. 268 . pp. 21-33. ISSN 1040-6182

Any correspondance concerning this service should be sent to the repository administrator: staff-oatao@,1istes-diff.inp-toulouse.fr 


\title{
Development and refinement of proxy-climate indicators from peats
}

\author{
Frank M. Chambers ${ }^{\mathrm{a}, *}$, Robert K. Booth ${ }^{\mathrm{b}}$, Francois De Vleeschouwer ${ }^{\mathrm{c}, 1}$, Mariusz Lamentowicz ${ }^{\mathrm{d}}$, \\ Gael Le Roux ${ }^{\mathrm{e}}$, Dmitri Mauquoy ${ }^{\mathrm{f}}$, Jonathan E. Nichols ${ }^{\mathrm{g}}$, Bas van Geel ${ }^{\mathrm{h}}$
}

${ }^{a}$ Centre for Environmental Change and Quaternary Research, Department of Natural and Social Sciences, University of Gloucestershire, Francis Close Hall, Swindon Rd, Cheltenham, GL50 4AZ, UK

${ }^{\mathrm{b}}$ Department of Earth and Environmental Science, Lehigh University, 31 Williams Drive, Bethlehem, PA 18015, USA

${ }^{\mathrm{c}}$ Department of Ecology and Environmental Science, Umeå University, SE-901 87 Umeå, Sweden

${ }^{\mathrm{d}}$ Department of Biogeography and Palaeoecology, Faculty of Geographical and Geological Science, Adam Mickiewicz University, Dzięgielowa 27, PL-61-680 Poznań, Poland

e EcoLab CNRS-Université de Toulouse, Campus Ensat, Avenue de l'Agrobiopole, BP 32607, Auzeville tolosane, 31326 Castanet-Tolosan, France

${ }^{\mathrm{f}}$ School of Geosciences, University of Aberdeen, Elphinstone Road, Aberdeen, AB24 3UF, UK

${ }^{g}$ NASA Goddard Institute for Space Studies, 2880 Broadway, New York, NY 10025, USA

${ }^{\mathrm{h}}$ Department of Paleoecology and Landscape Ecology, Institute for Biodiversity and Ecosystem Dynamics, Universiteit van Amsterdam, Science Park 904,1098 XH Amsterdam, The Netherlands

\begin{abstract}
A B S T R A C T
Peat, especially from acidic mires (bogs), is a natural archive of past environmental change. Reconstructions of past climate from bogs commenced in the 19th Century through examination of visible peat stratigraphy, and later formed the basis for a postglacial climatic scheme widely used in Northwest Europe. Nevertheless, misconceptions as to how bogs grow led to a 50-year lacuna in peat-climate study, before the concept of 'cyclic regeneration' in bogs was refuted. In recent decades, research using proxyclimate indicators from bogs has burgeoned. A range of proxies for past hydrological change has been developed, as well as use of pollen, bog oaks and pines and other data to reconstruct past temperatures. Most of this proxy-climate research has been carried out in Northern Europe, but peat-based research in parts of Asia and North America has increased, particularly during the last decade, while research has also been conducted in Australia, New Zealand and South America. This paper reviews developments in proxy-climate reconstructions from peatlands; chronicles use of a range of palaeo-proxies such as visible peat stratigraphy, plant macrofossils, peat humification, testate amoebae and non-pollen palynomorphs; and explains the use of wiggle-match radiocarbon dating and relationship to climate shifts. It details other techniques being used increasingly, such as biomarkers, stable-isotopes, inorganic geochemistry and estimation of dust flux; and points to new proxies under development. Although explicit protocols have been developed recently for research on ombrotrophic mires, it must be recognised that not all proxies and techniques have universal applicability, owing to differences in species assemblages, mire formation, topographic controls, and geochemical characteristics.
\end{abstract}

\section{Introduction}

The use of peat, especially from acidic mires (bogs), as an archive for climatic and environmental change is long-standing. There was a notable advance near the close of the 19th century: peat stratigraphy in Scandinavia provided the first climatostratigraphic division of the Holocene-the Blytt-Sernander scheme (Blytt,

\footnotetext{
* Corresponding author.

E-mail address: fchambers@glos.ac.uk (F.M. Chambers).

1 Present address: EcoLab CNRS-Université de Toulouse, Campus Ensat, Avenue de l'Agrobiopole, BP 32607, Auzeville tolosane, 31326, Castanet-Tolosan, France.
}

1876; Sernander, 1908), whose terminology has been used in north-west Europe for a century. However, a prevailing misconception as to how bogs grow delayed their detailed exploitation as climatic archives until the 1970s (see Backéus, 1990), when Aaby (1976) reported cyclic, sub-Milankovitch-scale climate changes within the late Holocene. His interpretation was based on colorimetric peat humification and rhizopoda (testate amoebae) data from Danish peat cores (Aaby and Tauber, 1975). Based on studies at Bolton Fell Moss, northern England, Barber (1981) refuted the internal (autogenic) cyclic regeneration hypothesis-the prevailing paradigm that had inhibited climate research on bogs-and instead proposed that raised mires provided a continuous record of past hydroclimatic change, as they were 'directly coupled' to the 
atmosphere. Barber et al. (1994) then showed how plant macrofossil analysis could be used to provide a semi-quantiative record of past climate variability. Though omitted as a climate archive from the Bradley (1999) compendium, studies on bogs in north-west and west-central Europe have gained greater prominence during the last decade (Chambers and Charman, 2004; Chambers et al., 2010). A wide array of climate proxies has been developed, involving an increasing number of specialists from a range of disciplines (de Jong et al., 2010).

\subsection{Geographical scope}

Most of the peatland proxy-climate research has been carried out in Northern Europe, where peat-climate research has concentrated principally on two mire types: blanket mires (mainly in western Ireland and the UK uplands, but also western Norway), and raised mires (located especially in central Ireland; lowlands in parts of the north, west and east of Britain; Denmark; northern Germany; Southern Sweden; Estonia; southern Finland; Poland; Czech Republic). However, peat-based palaeoclimate research has increased in parts of Asia, notably in China (Hong et al., 2000, 2001; Xu et al., 2006; Seki et al., 2009) and Indonesia (Weiss et al., 2002), and in North America (Booth et al., 2006; Hughes et al., 2006; Booth, 2010; Loisel et al., 2010), particularly during the last decade, while research has also been conducted in Australia (Kylander et al., 2007; Muller et al., 2008), New Zealand (Wilmshurst et al., 2002) and South America (van Geel et al., 2000; Mauquoy et al., 2004a; Chambers et al., 2007a).

\subsection{Advantages of ombrotrophic mires for palaeoclimate reconstruction}

Ombrotrophic mires have accumulated peat during the mid-late Holocene epoch, with some in temperate regions from the early Holocene, or for longer in the case of tropical peatlands. Ombrotrophic mires are fed by atmospheric inputs (aerosols, rain, etc.), and so, like ice cores, can therefore provide past environmental records of the atmosphere. They have three main advantages compared to other environmental archives: (i) a widespread distribution around the globe, providing better accessibility, global distribution and ease of sampling (e.g. compared to ice cores); (ii) because peat almost exclusively constitutes autochthonous organic matter, they can be dated using radiocarbon techniques, leading to high-resolution and low-uncertainty chronologies (e.g. compared to non-varved lake sediments); and (iii) a largely atmospheric signal, as they are isolated from groundwater (e.g. compared to lake and coastal sediments). Therefore, ombrotrophic mires provide a valuable archive to investigate climate-environment relationships and palaeoenvironmental change.

\subsection{Aims and organisation of the paper}

This paper conducts a critical review of developments in proxyclimate reconstructions from peat. For simplicity, techniques have been grouped in the text into five categories (see also Table 1): (i) well-established methods and techniques, such as use of visible peat stratigraphy, plant macrofossils, peat humification, testate amoebae and non-pollen palynomorphs; (ii) the wiggle-matching of series of radiocarbon dates and their relationship to climate shifts; (iii) organic biomarker and stable-isotope techniques that are being increasingly applied; (iv) geochemical techniques, the range of which is increasing; (v) new techniques under development. Emphasis is placed on recent applications and examples of techniques-especially geochemical, to help forge better links between geochemists and mire palaeoecologists. In addition, there
Table 1

Examples of proxy-climate indicators and dating techniques for Late-Quaternary peat (modified and adapted from Chambers, in press).

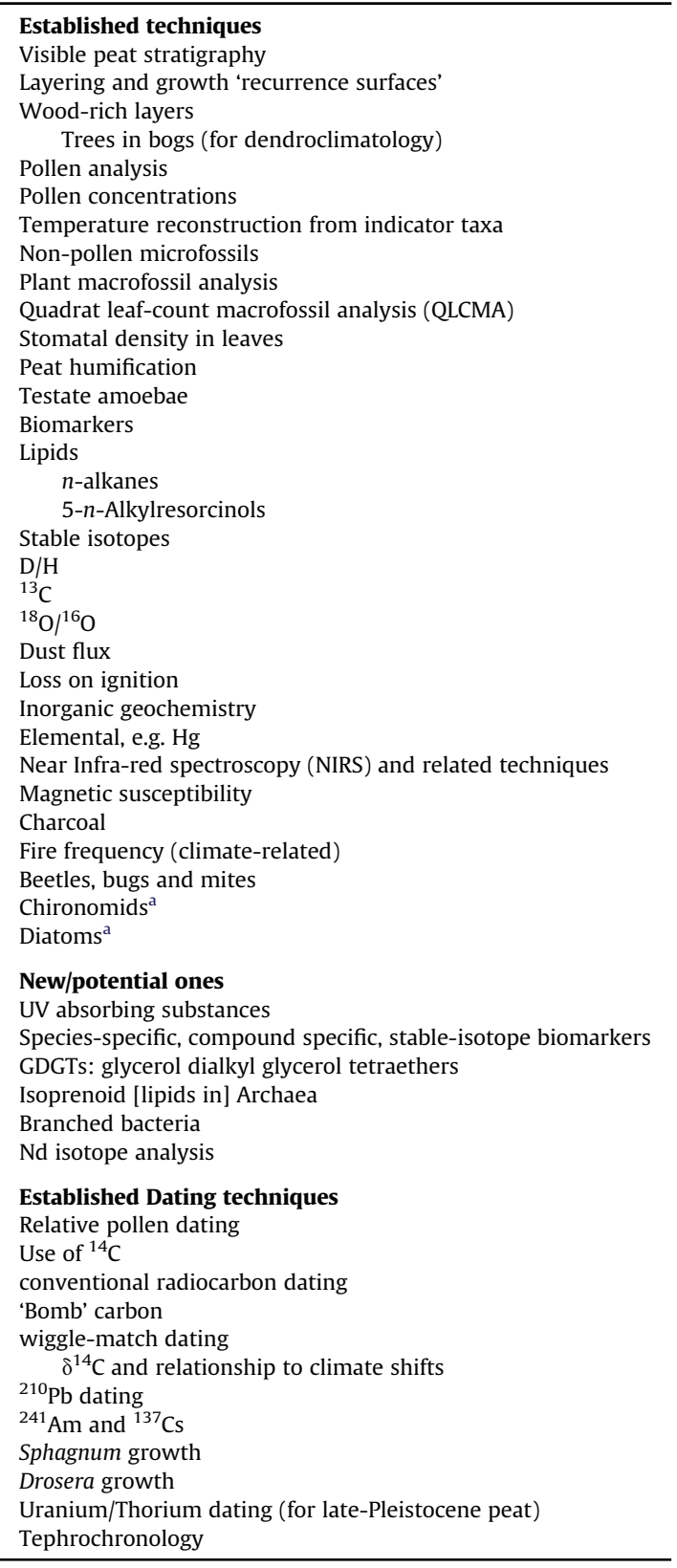

a seldom used for peat; more often used for lake mud.

are other biological techniques that are well-established in Quaternary science, such as analysis of pollen, beetles and treerings, but for which peat is but one terrestrial archive in which they may be found. These are not considered further here.

\section{Established methods and techniques}

Several methods and techniques have become established and widely used for palaeoclimate reconstruction, though some of these continue to be refined.

\subsection{Visible peat stratigraphy}

The transition from dark, highly decomposed peat to fresh, light-coloured peat around $850 \mathrm{cal}$. BC is one of the most 
pronounced visible transitions observed in north-west European raised mires (Fig. 1). In their subdivision of the Holocene the Scandinavians Blytt and Sernander (Blytt, 1876, 1882; Sernander, 1908) used it as a boundary between the supposedly relatively dry and warm Subboreal and the relatively cool and wet Subatlantic. In an early stage of peat research Granlund (1932) described additional contacts between dark and light peat in raised mires in southern Sweden. He called these transitions Rekurrensytor (RY: recurrence surfaces), indicating transitions from highly decomposed peat that had been growing relatively slowly and under dry conditions, to peat that showed indications for growth under wetter conditions. Granlund distinguished RY-I to $\mathrm{RY}-\mathrm{V}$ and supposed that these had been triggered by climate shifts to cooler, wetter conditions. Based on palynological and archaeological information the changes were dated 2300 BC, 1200 BC, 600 BC, AD 400 and AD 1200. During later peat stratigraphical studies in Scandinavia and elsewhere in north-west Europe it was expected that the identification and dating of the RYs would lead to a better knowledge of Holocene climate change. However, it soon became evident that even within one raised mire the contact levels appeared to have different ages (Lundqvist, 1962) and some RYs either could not be detected, or were barely recognisable, in different raised mire complexes because of local hydrological differences. Overbeck (1975) referred to different factors that could play a role in the presence or absence/and differentiation of the expression of RYs: size of the bog; age of its base; lesser or more pronounced raised surface; fluctuations in the undulation of the basal topography and related hydrographical conditions; and regional differences in climate.

Even after introduction of the radiocarbon dating method the diagnostic climatological value of RYs remained questionable. The 'boundary horizon' (German: Grenzhorizont) originally considered as a synchronous phenomenon caused by a major climate shift at the Subboreal-Subatlantic transition appeared not to be a time horizon (Overbeck, 1975, and references therein). However, in detailed studies of vegetation changes in raised mires, van Geel (1978) showed that humification changes are less indicative of climate change than changes in Sphagnum species composition. The sudden appearance of S. imbricatum in Wietmarscher Moor in Germany, Engbertsdijksveen in the Netherlands and Carbury Bog in Ireland characterizes the Subboreal-Subatlantic transition (see also van Geel et al., 1998), while major changes in humification (SWK: German abbreviation for contact between black and white peat) were not synchronous. In the original work on recurrence surfaces, a major increase in the atmospheric radiocarbon content between 850 and $760 \mathrm{cal} \mathrm{BC}$ (creating a rapid rate of change in the

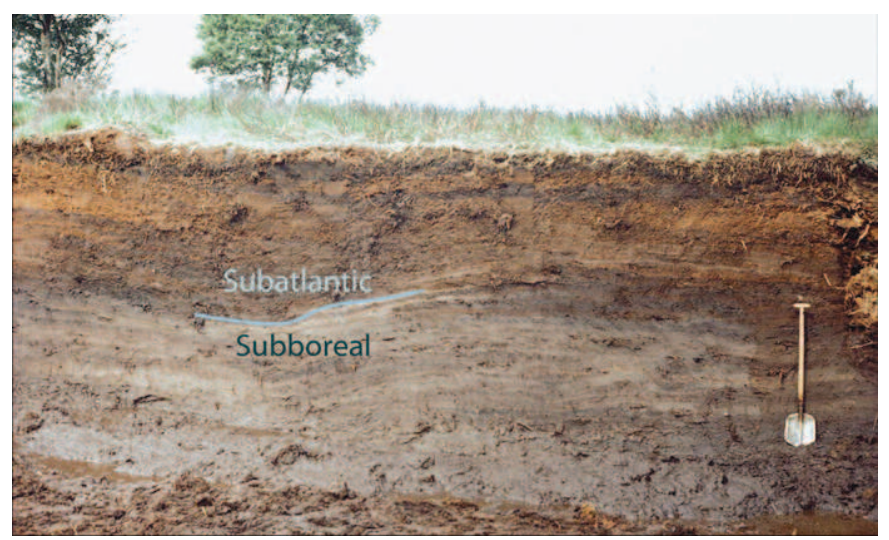

Fig. 1. The Subboreal-Subatlantic transition of c. $2800 \mathrm{cal}$. BP in a raised mire peat profile in The Netherlands. 'radiocarbon clock' during this time period) followed by a decline of atmospheric radiocarbon (creating a plateau in the calibration curve) was not recognised and understood, leading to supposed asynchrony of recorded wet shifts (but see Section 3).

\subsection{Plant macrofossils}

A combination of high decay resistance, low $\mathrm{pH}$ and waterlogged conditions in raised mires normally ensures excellent preservation of mosses (mainly Sphagnum species). Roots and epidermal tissues of graminoids are also often preserved, as well as leaves, stems and seeds of dwarf shrubs (e.g. Ericaceae, Empetrum). Sample pretreatment is simple for the Quadrat Leaf Count method (see Mauquoy et al., 2010/11 for detailed description). Species-level identification of a range of mosses, graminoids and dwarf shrubs is possible using reference type material (both sub-fossil and modern) and drawings, keys and plates (Grosse-Brauckmann, 1972a,b; Grosse-Brauckmann and Streitz, 1992; Katz et al., 1977; Smith, 2004; Mauquoy and van Geel, 2007). Preservation of macrofossils in blanket mires is variable, but sometimes poor, given the higher degree of water-table fluctuation and degree of humification, and slower growth rate in these ecosystems.

Analyses of plant macrofossils can be used to reconstruct peatland vegetation development at the micro- and mesoform level in order to determine successional development and pathways (Hughes and Barber, 2004), reconstruct mire surface wetness as a palaeoclimate proxy (Swindles et al., 2007; Mauquoy et al., 2008), in addition to providing evidence for plant-species mediated changes in long-term carbon sequestration (Mauquoy et al., 2002; Heijmans et al., 2008; Sannel and Kuhry, 2009), and discerning the relative influence of climate change and recent human impact on moorland and blanket mires (Chambers et al., 1999, 2007b,c).

Mire surface wetness reconstructions have largely been made from the identification of phases of relatively low local water tables (showing increased representation of hummock microform Sphagna and Calluna vulgaris/Empetrum nigrum) and phases of higher local water-table depths (with aquatic, pool Sphagna and Rhynchospora alba/Eriophorum angustifolium). Ordination techniques (PCA and DCA) have been used to create a single index of mire surface wetness based on the total sub-fossil dataset for a peat profile (Barber et al., 1994; Mauquoy et al., 2004b; Sillasoo et al., 2007), in which it is assumed that the principal axis of variability in the dataset is linked to hydrology. Quantitative reconstructions of local water-table depths are also possible, based on water table/ surface vegetation modelling (Väliranta et al., 2007). Nevertheless there are problems in using these techniques. For example, in using DCA, Barber et al. (1994) had to combine the records of Sphagnum magellanicum with $S$. imbricatum, because otherwise the first component in the data was the stratigraphic difference between the lower horizons dominated by S. imbricatum, and the upper horizons, dominated by $S$. magellanicum, which seemed to be its direct replacement. This example cautions researchers to be fully aware of the patterns in the dataset, and not to assume that the first component will automatically be hydrological.

The accurate identification of plant macrofossils in peat deposits is desirable so as to ensure the selection of appropriate plant material for radiocarbon dating, to facilitate the creation of accurate ${ }^{14} \mathrm{C}$ chronologies. Above-ground macrofossils can be selected preferentially for dating, while the roots of graminoids and Ericaceae should be avoided because these have been shown to produce ages that are too young, given their downward growth into the peat profile (Kilian et al., 2000). Even carefully selected Sphagnum leaves and stems need to be checked carefully to ensure there are no fungal hyphae within. 
Future work could involve inter-hemispheric comparison of reconstruction of mire surface wetness, for those types of mire where it is feasible to use the Quadrat Leaf Count method. In future, this technique should always be used in combination with others, in multi-proxy studies.

\subsection{Peat humification}

The analysis of peat humification of ombrotrophic peat deposits is a widely used palaeoclimate proxy. Peat humification is a measure of organic decay and has been thought mainly to reflect changing palaeohydrological conditions in the slim, upper layer of a diplotelmic mire: the acrotelm. This upper layer experiences a seasonally fluctuating water table, and in dry conditions can experience high decay rates. Because decay processes are very much slower in the anaerobic catotelm than in the acrotelm (Belyea and Clymo, 2001), the degree of peat humification is thought to represent the environmental conditions at the time of peat accumulation (Aaby and Tauber, 1975; Blackford and Chambers, 1993). A revised protocol is included in Chambers et al. 2010/11). The technique, which is reviewed within de Jong et al. (2010), is particularly advantageous in relatively highly decayed peats in which plant macrofossils are less easily identified, and hence it is frequently used to generate a proxy-climate record from blanket mires (e.g. Nilssen and Vorren, 1991; Chambers et al., 1997).

A cautionary note was sounded by Yeloff and Mauquoy (2006), who identified inconsistencies between peat humification and other proxy-records of mire surface wetness in a peat profile. The humification signal is a derived response to climate. The assumption that climate has been the major influence on variations in humification rests on the supposition that the botanical composition is relatively homogeneous throughout a peat profile; however, that is often not the case, making the use of humification data (on their own) as a climate proxy questionable (Yeloff and Mauquoy, 2006), because past changes in the botanical composition of the peat may have an influence on humification measurements, as acknowledged by Chambers et al. (1997), who recognised the possibility of a 'species signal' in humification data. Caseldine et al. (2000) questioned the assumption that the colorimetric technique, which uses weak alkali as a digestant, actually extracts 'humic acid'. Morgan et al. (2005) investigated this further using size-exclusion chromatography in 1-methyl-2-pyrrolidinone. Despite these reservations, one advantage of analysis of humification (over the analysis of plant macrofossils or of testate amoebae) is that it is operator-independent, provided a strict time schedule (owing to fading of the extract) is adhered to.

Future developments would be to focus peat humification on peat cores from mires with long records of single-taxon dominance (e.g. Sphagnum austinii [syn S. imbricatum ssp. austinii)] in Northwest Europe; S. magellanicum in Patagonia), to avoid the claimed 'species signal', and to conduct stable-isotope analyses on these single species in those same peat cores (see Section 4.2).

\subsection{Use of testate amoebae}

Testate amoebae, a group of amoeboid protozoans that produce morphologically distinct shells, are commonly used as surfacemoisture proxies in peat-based palaeoclimate studies (Mitchell et al., 2008a). Although the moisture sensitivity of these organisms has been recognised for over a century (Leidy, 1879; Jung, 1936), work over the past several decades has demonstrated the utility of testate amoebae as quantitative surface-moisture indicators. High sensitivity to moisture variation has been demonstrated by coherence in reconstructions of wet and dry fluctuations within and between mires (Hendon et al., 2001; Booth et al., 2006).
Advantages of using testate amoebae in peat-based palaeoclimate studies include their rapid response time to environmental changes, the ease with which community composition can be quantified using standard light microscopy, the small sample volumes needed for analysis (i.e., $0.5-1 \mathrm{~cm}^{3}$ ), and the ability to reconstruct past water-table depths quantitatively, including associated error estimates (Charman et al., 2000; Charman, 2001; Mitchell et al., 2008a). A protocol is provided by Charman et al. (2000) and by Booth et al. (2010).

The calibration and validation of testate amoebae as palaeoclimate proxies has occurred in two ways. First, present-day community-environment relationships have been studied within many regions, allowing the development of transfer functions to infer moisture conditions from testate amoeba communities (e.g., Woodland et al., 1998; Mitchell et al., 1999; Lamentowicz and Mitchell, 2005; Charman et al., 2007; Booth, 2008; Lamentowicz et al., 2008; Payne et al., 2008; Swindles et al., 2009; Markel et al., 2010). These studies have clearly revealed that water-table depth is strongly correlated with community composition, and transfer functions can typically estimate water-table depths with a mean error of less than about $8 \mathrm{~cm}$ (Fig. 2a). In addition, comparison of water-table depths estimated from sub-fossil testate amoeba assemblages and instrumental records of climate for the past several centuries have provided additional validation for their use in studies of past hydroclimate variability (Fig. 2b), and have greatly advanced understanding of the climatic response of mires (Schoning et al., 2005; Charman, 2007; Charman et al., 2009; Booth, 2010). For example, testate amoeba-inferred water-table depths generally reflect the length and severity of the summer moisture deficit, which at least in raised mires is primarily controlled by summer precipitation (Charman, 2007; Charman et al., 2009). Temperature generally has a secondary control through its effect on evapotranspiration rate (Charman, 2007). Therefore it is not surprising that particularly strong correlations have been found between integrated moisture indices (e.g., Palmer Drought Severity Index) and reconstructed water-table depths (Booth, 2010) (Fig. 2b).

Additional research is still needed on the ecology and palaeoecology of testate amoebae to refine the interpretation of palaeohydrological records. For example, taphonomic studies are needed to assess the potential effect of differential decomposition of tests on palaeohydrological reconstructions, although recent research suggests that these effects are minimal (Mitchell et al., 2008b). Studies on the ecology of testate amoebae also inform palaeoenvironmental interpretations, and although numerous studies have now provided a wealth of data on moisture tolerances and optima for most common species, there are still remaining questions. For example, the response of testate amoeba communities to seasonal-to-interannual moisture variability (Warner et al., 2007), the role of surface vegetation in modulating the microenvironment of testate amoebae, and the potential for factors besides surface moisture to influence testate amoeba community composition all need to be better understood (Lamentowicz et al., 2010; Markel et al., 2010). Experimental studies are needed to address some of these issues and to characterise better the proximal controls (e.g., resources) on testate amoeba communities, and assess how these proximal controls are affected by water-table depth. Population and community modelling efforts should be used in tandem with experimental and observational approaches to test models of community assembly and structure. Improvements in taxonomy, as well as the investigation of environmental controls on test morphology, also have the potential to improve reconstructions of past environmental change (e.g., Booth and Meyers, 2010; Payne et al., in press). The use of testate amoebae as indicators of past climate will benefit from increased collaborative work among taxonomists, ecologists, and palaeoecologists (Mitchell et al., 2008a). 
a Jacknifed validation of testate amoeba transfer function for water-table depth in eastern North America

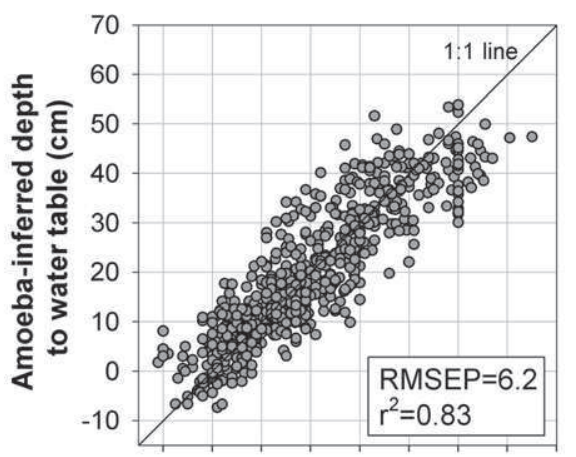

$\begin{array}{lllllllll}-10 & 0 & 10 & 20 & 30 & 40 & 50 & 60 & 70\end{array}$

Measured water-table depth $(\mathrm{cm})$

\section{b Composite surface-moisture reconstruction from} three peatlands and instrumental record of PDSI
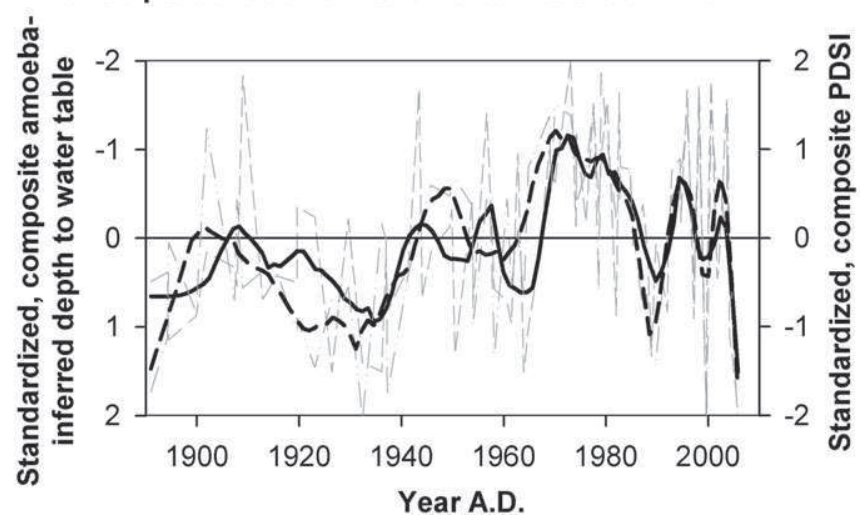

Fig. 2. Validation of the hydrologic and climatic sensitivity of mire surface-moisture reconstructions. a) Cross-validation of testate amoeba transfer function for mean annual water-table depth, based on over 650 samples from North American bogs (modified from Booth, 2008). b) Comparison of a composite testate amoebae-inferred paleohydrological reconstruction (depth to water table) derived from three ${ }^{210} \mathrm{~Pb}$ dated bog records (faint continuous line) and instrumental records of Palmer Drought Severity Index (PDSI; (faint dashed line) (data from Booth, 2010). Thick lines show approximately decadal-scale smoothing of the composite datasets (thin lines).

\subsection{Inter-proxy comparisons}

A striking correspondence can be seen between different climate proxies in some peat records (se Fig. 3), which is encouraging. Questions that remain to be answered regarding the three foregoing techniques (in section2.2, section2.3 and section2.4) are (i) why the data produced by each technique sometimes give contrasting results or opposing tendencies within parts of a peat core; and (ii) which of the three techniques is most reliable for reconstructing past climate. Hughes et al. (2006) circumvented the problem by taking the majority indication, but a more satisfactory resolution of these questions is required. Each technique has conventionally been assumed to indicate the direction of hydrological change (drier/wetter), rather than temperature (warmer/ cooler), but the contribution of summer temperature (to water table drawdown and decay processes) at times of more continental past climate may require further consideration, as also may the effects of prolonged snow cover (on vegetation). Each proxy is likely responding to somewhat different environmental factors, and understanding these differences will potentially allow more robust extraction of the climatic signals as well as possibly the identification of different aspects of climate variability (temperature, precipitation, seasonality, etc.)

\subsection{Non-pollen palynomorphs in raised mire deposits}

In pollen preparations, other microfossils are also preserved. Among the 'non-pollen palynomorphs' or NPP found in peat are various spore types of fungi and spores of Zygnemataceae (green algae). In a series of papers the descriptions and illustrations of many non-pollen palynomorphs were published and their indicator value was discussed (van Geel, 1978, 1986, 2001; van Geel et al., 1995, 2003; van Geel and Aptroot, 2006; van Geel and Grenfell, 1996). Morphological descriptions and pictures were combined with stratigraphic information, often in the form of pollen and macrofossil diagrams. In most cases there was initially no, or hardly any taxonomic/ecological knowledge about these NPP. The identification of the fossils was attempted with the aid of literature and by consulting colleagues in mycology, phycology and invertebrate zoology. Among the NPP there are still many taxa that are not properly identified, but some of them nevertheless can be used as palaeoenvironmental indicators. In such cases, the ecological information was inferred from the co-occurrence (curve matching) with identified microfossil and macrofossil taxa. For NPP in raised mire peat the publication by van Geel (1978) is relevant. The up-to-now unidentified 'Type 10' appeared to be linked with the roots of $C$. vulgaris and-like its host plant-it is a dryness indicator. The parasitic fungus Meliola ellisii ('Type 14') is also strongly linked with $C$. vulgaris.

Yeloff et al. (2007) assessed the potential of fungal microfossils in raised mire deposits for palaeoclimate reconstruction. The relationship between fungal types, vegetation components and water-table depth reconstructions derived from testate amoebae assemblages was explored. Yeloff et al. evaluated environmental preferences of fungi by assessing the relationships among fungal types, the peat-forming vegetation, the occurrence of fire, and water-table status in fossil and modern samples from two raised mires in northern England and Denmark. Water is one of the most important environmental factors defining the habitat of terrestrial fungi, and fungi preserved in ombrotrophic peat deposits can indicate past variations in surface wetness and vegetation composition. The microfungi are generally indicators of relatively dry (hummock-like) conditions. Several fungal microfossil types can be used to provide a qualitative reconstruction of past conditions on the surface of the mire, and accurately indicate shifts between relatively dry and wet local conditions. Some of the more abundant types, particularly 'Type 12 ' spores, show a characteristic distribution with water-table depth. In addition to testate amoebae, fungal spores are useful for quantitative reconstructions of past water tables and therefore climate in ombrotrophic mires (Yeloff et al., 2007).

\section{Wiggle-match series of dates: $\Delta^{14} \mathrm{C}$ and relationship to climate shifts}

Holocene peat deposits, especially the rainwater-fed raised mires such as those in Northwest Europe, have become regarded as natural archives of climate change (Barber, 1981, 2006; Barber and Langdon, 2007); hence, climate-related changes in precipitation and temperature are believed reflected in the changing species composition of the peat-forming vegetation (Section 2.2). The radiocarbon method is generally used for the dating of assumed climate-induced vegetation shifts in Holocene peat deposits. The cosmogenic radionuclide ${ }^{14} \mathrm{C}$ is produced continuously in the atmosphere as a result of the interaction of galactic cosmic rays with nitrogen, but ${ }^{14} \mathrm{C}$ production is not constant. Changing solar 


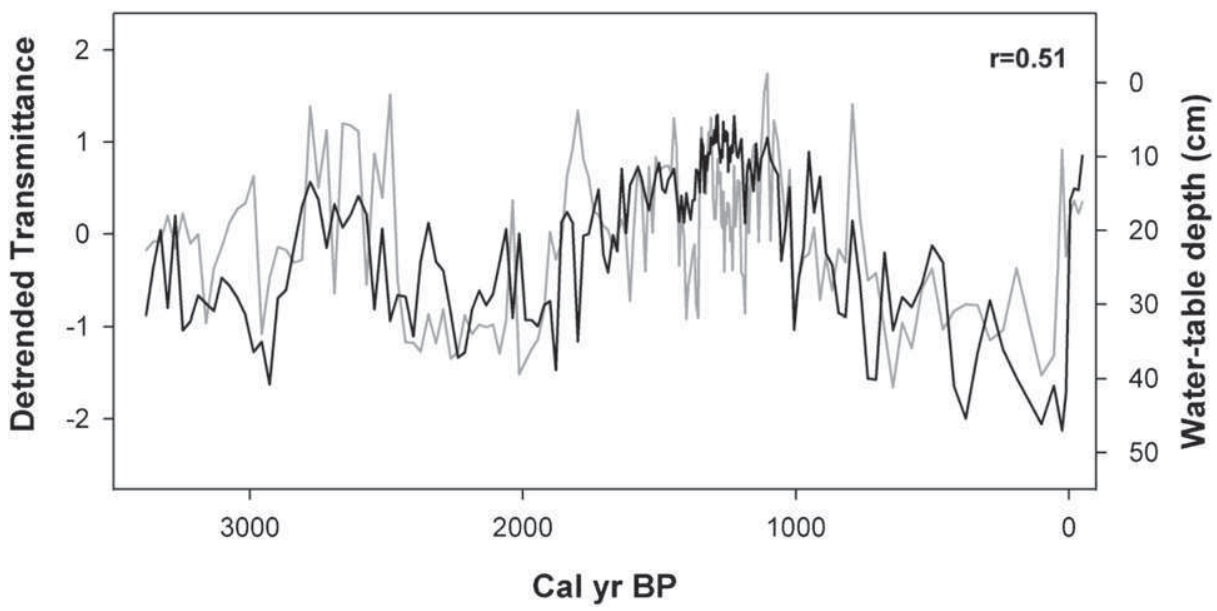

Fig. 3. Peat humification (shown as light-transmittance data) and water-table depth reconstruction (from testate amoebae data) for the past 3400 years from Minden Bog, Michigan, USA. Note the close correspondence of the two mire-based proxy-climate measures for the majority of the record.

activity modulates the cosmic ray intensity through the effects of the solar wind. Changes of solar activity can be derived from measurements of radiocarbon in tree-rings. Atmospheric ${ }^{14} \mathrm{C}$ fluctuations during the Holocene epoch are thought to reflect mainly changes in solar activity (Beer and van Geel, 2008).

Calibration of a single radiocarbon date usually yields an irregular probability distribution of calendar ages, quite often over a long time interval. This is problematic in palaeoclimatological studies, especially when a precise temporal comparison between different climate proxies is required. Closely spaced sequences of (uncalibrated) ${ }^{14} \mathrm{C}$ dates from peat deposits, however, display wiggles that can be fitted to the wiggles in the radiocarbon calibration curve. The practice of dating peat samples using ${ }^{14} \mathrm{C}$ "wiggle-match dating" has greatly improved the precision of radiocarbon chronologies since its application by van Geel and Mook (1989). By wiggle-matching ${ }^{14} \mathrm{C}$ measurements, highprecision calendar age chronologies for peat sequences can be generated (Kilian et al., 1995; Blaauw et al., 2003), which show that in some locations, mire surface wetness increased together with rapid increases of atmospheric production of ${ }^{14} \mathrm{C}$ during the early Holocene, the Subboreal-Subatlantic transition (2650 BP; $2800 \mathrm{cal}$. $\mathrm{BP}$ ), and the Little Ice Age (Wolf, Spörer, Maunder, and Dalton minima of solar activity). Because the production of radiocarbon is regulated by solar activity, periods of increased mire surface wetness in continental Europe have been interpreted as evidence for sudden declines in solar activity. Peat studies using the same macrofossil technique (Section 2.2) show that the phenomenon at 2800 cal. BP (see Fig. 1) occurred in The Netherlands (Kilian et al., 1995; van Geel et al., 1998; van der Plicht et al., 2004), the Czech Republic (Speranza et al., 2003), Britain and Denmark (Mauquoy et al., 2002), and at the same time but with an apparently opposite response (to short-lived dryness) in a mire in Tierra del Fuego (Chambers et al., 2007a).

The information from raised mires does not stand alone. Denton and Karlén (1973) linked the radiocarbon record with geologic data such as the extension of glaciers and made important conclusions about solar forcing of climate change. Magny $(2004,2007)$ published a long record of Holocene climate-related water table changes in lakes in south-eastern France and adjacent Switzerland. The lake-level fluctuations closely correspond with the atmospheric ${ }^{14} \mathrm{C}$ fluctuations and therefore also with the cosmogenicisotope derived history of solar activity. Lake levels were low during periods of high solar activity (low values of $\Delta^{14} \mathrm{C}$ ), whereas high lake-stands occurred when solar activity was low. The lake sediment records published by Magny and co-workers have delivered data showing that lakes may be even better sensors for the registration of climate change than raised mires, but the advantage of raised mires is that the peat accumulation is (arguably) continuous and wholly autochthonous, and is seldom subject to problems of erosion, unlike lake-shore environments.

\section{Abundances and stable-isotope ratios of organic biomarkers in peat as indicators of climate change}

\subsection{Organic biomarkers}

Organic biomarkers are recalcitrant compounds whose origin can be traced to a particular taxon. The term "biomarker" can refer to general indicators of broad groups of organisms, or to specific genera or species. Biomarkers used in environmental reconstructions typically come from the membrane lipids of unicellular organisms or the epicuticular waxes of plants, though the latter are more commonly used in peat-based climate reconstruction (e.g. Bingham et al., 2010). For example, saturated hydrocarbons and their homologues ( $n$-alkanes, $n$-fatty acids, and $n$-fatty alcohols) are typical examples of general plant biomarkers. In mires, the shorter chain varieties of these molecules (20-26 carbons) are produced mainly by Sphagnum, while the longer chain varieties (26-34 carbons) are produced mainly by vascular plants (Baas et al., 2000; Nott et al., 2000; Pancost et al., 2002; Nichols et al., 2006). Specific biomarkers, produced by plants belonging to only one genus, have also been identified. These include 5- $n$-alkylresorcinols, a biomarker for the family Cyperaceae (Avsejs et al., 2002) and $n$-alkan-2-ones, a biomarker for the genus Sphagnum (Nichols and Huang, 2007).

Biomarker compounds can be used to create environmental reconstructions in a similar manner to traditional fossils. For example, several indices describing variations in relative abundance of different n-alkyl homologues have been developed to describe different climatic and sedimentary processes. One example is the Sphagnum/Vascular Ratio (SVR), which uses the relative abundance of $\mathrm{C}_{23} \mathrm{n}$-alkane and $\mathrm{C}_{29} n$-alkane as a moisture balance indicator. Sphagnum (which thrives under wet conditions) produces more $C_{23} n$-alkane than other alkanes, while vascular plants (which generally prefer lower water-table depths) produce mainly $C_{29} n$-alkane (Nichols et al., 2006). The Carbon Preference Index (CPI) describes the odd over even carbon-number preference of sedimentary n-alkanes. Plants produce only odd carbon- 
numbered n-alkanes, but as microbial or thermal processes degrade sediment, this preference is slowly erased. The CPI indicates how much degradation the wax fraction has undergone (e.g., Zhou et al., 2005). Because degradation of waxes by microbial action can be moderated by environmental conditions, particularly temperature, the CPI can also be used to infer climate changes. This compound class, however, is quite resistant to degradation, and so this index can even be used in peat sequences spanning the order of $10^{4}$ years or more.

\subsection{Use of stable-isotope measurements}

Peat or its components has been investigated for isotopes of oxygen, hydrogen and carbon. Protocols for these techniques will be published in the volume edited by De Vleeschouwer et al. (2010a).

\subsubsection{Oxygen isotopes}

Oxygen isotope ratios are typically measured from cellulose extracted from peat. Such work started nearly 30 years ago in Europe (e.g. Brenninkmeijer et al., 1982; Dupont and Brenninkmeijer, 1984; Ménot-Combes et al., 2002), and has been applied in Asia (Hong et al., 2000). Cellulose is converted first to nitrocellulose to eliminate exchangeable oxygen atoms from the molecule. The cellulose itself can be extracted from bulk peat, or from specific macrofossils. Picking macrofossils for isotope analysis can be time-consuming, and can result in low cellulose yields, as compared with bulk peat. However, isotope measurements from taxon-specific cellulose, such as from Sphagnum, are much easier to interpret (e.g. Daley et al., 2009).

\subsubsection{Hydrogen isotopes}

The stable-isotope composition of precipitation is an extremely useful parameter for palaeoclimate reconstruction and provides information about temperature, rainfall amount, and moisture source. Hydrogen isotopes are typically measured from leaf-wax biomarkers ( $n$-alkanes and $n$-fatty acids) using an isotope-ratio mass spectrometer coupled to a gas chromatograph through a continuous flow device. The leaf waxes of vascular plants found in sediments of aquatic systems have been used to reconstruct the hydrogen isotopic ratios of precipitation (e.g. Sachse et al., 2006; Hou et al., 2007), and have also recently been used in peats (Seki et al., 2009). Ombrotrophic mires are particularly well suited to reconstructing precipitation isotopes with vascular plant leaf waxes because the only input of water to these systems is by direct precipitation (Nichols et al., 2009, 2010).

While the hydrogen isotope ratios of vascular plant biomarkers can be used to reconstruct precipitation, the hydrogen isotopic composition of Sphagnum molecules is influenced by two factors. These are the $\delta \mathrm{D}$ of the precipitation and enrichment by evaporation of water inside and between the Sphagnum leaves. The contrast between the hydrogen isotope ratios of Sphagnum and vascular plant biomarkers has been used to estimate the amount of evaporation occurring at the surface of the mire (Nichols et al., 2010).

\subsubsection{Carbon isotopes}

Carbon isotopes in peat can be measured both from cellulose (e.g. Hong et al., 2001) and from leaf-wax compounds. Two opposing factors are thought to influence the carbon isotope ratio of fossil Sphagnum molecules from cellulose, leaf waxes, etc. The first is the carbon isotope ratio of the $\mathrm{CO}_{2}$ used for photosynthesis. A methanotrophic bacterium lives symbiotically with Sphagnum in its hyaline (water-holding) cells (Raghoebarsing et al., 2005). Because the $\delta^{13} \mathrm{C}$ value of biogenic methane is so low, $(-40 \%$ to $-60 \%$ ) it can dramatically affect the ultimate $\delta^{13} \mathrm{C}$ of the Sphagnum molecules. Higher methane fluxes under wet conditions lead to more assimilation of $\mathrm{CH}_{4}$-derived $\mathrm{CO}_{2}$ and thus lower carbon isotopic ratios of Sphagnum biomarkers. Up to $15 \%$ of the $\mathrm{CO}_{2}$ used by Sphagnum can come from recycled methane (Raghoebarsing et al., 2005). The amount of recycled $\mathrm{CO}_{2}$ available to Sphagnum is influenced mainly by the wetness of the mire surface. When the mire is wetter, more methane-derived $\mathrm{CO}_{2}$ is available at the surface for use by Sphagnum $\left(\delta^{13} \mathrm{C}\right.$ decreases). However, wetness of the Sphagnum itself also directly influences the $\delta^{13} \mathrm{C}$ of its molecules. When the Sphagnum plant is more saturated the water film over the photosynthetic cells impedes the incorporation of $\mathrm{CO}_{2}$ and so the plant becomes less selective against ${ }^{13} \mathrm{C}$ (Williams and Flannagan, 1996). Because of these competing influences, and the possible influence of other factors like temperature (Skrzypek et al., 2007), $\delta^{13} \mathrm{C}$ records derived from peat sequences must be evaluated carefully (Markel et al., 2010), and in the context of other reconstructed parameters.

\section{Inorganic geochemistry of peat as a palaeoclimatic indicator}

The fluxes, particle size, mineralogy, and chemistry of atmospheric mineral dust may affect the Earth's climate system, the chemistry of the atmosphere, and the global biogeochemical cycles of many elements (Goudie and Middleton, 2001; Harrison et al., 2001). Mineral dust in the atmosphere may modify the Earth's radiation budget through the absorption and scattering of incoming solar and outgoing terrestrial radiation, act as condensation nuclei to promote the formation of clouds, and adsorb many chemicals because of their reactive surface areas.

It is possible to investigate the geochemistry of preserved mineral materials in peat using modern analytical methods, to distinguish between their predominant atmospheric sources, quantify their rates of deposition, and study their variation through time (Bindler, 2006). In addition to classic geochemistry, developments in isotope geochemistry either for light elements (C, N, O, S; see Section 4.2), heavy elements ( $\mathrm{Pb}, \mathrm{Nd}$ ) or non-traditional intermediate metals $(\mathrm{Hg}, \mathrm{Cu}, \mathrm{Zn})$ open new fields of research giving information on the sources and mechanisms of atmospheric deposition recorded in peat cores. For example, $\mathrm{Hg}$ has been interpreted by Martínez-Cortizas et al. (1999) as capable of providing a direct climate signal from peat.

\subsection{Analytical techniques}

Direct dust analyses can be performed after extraction on peat ashes using soft acids and bases and particle collection by filtration and/or centrifugation (Givelet et al., 2004). This is particularly relevant for large mineral particles like quartz grains and minerals that are resistant to peat acidic conditions, such as aluminosilicates or zircon (Le Roux and Shotyk, 2006). In peat cores from coastal sites, the record of quartz grains was used to derive Holocene storminess variability in Scandinavia (de Jong et al., 2006; Björck and Clemmensen, 2004). However, many minerals, including some produced by volcanic eruptions, are weathered in peat environments. Thus it is necessary to find fingerprints of dust variability and fluxes.

There are numerous techniques dedicated and optimised for peat geochemical analyses. These range from bulk, non-destructive elemental analyses, such as X-ray fluorescence (XRF), to (highresolution) inductively coupled plasma mass spectrometry (e.g. ICP-MS, HR-ICP-MS). The limiting factor of XRF is the relatively high detection limit for some trace elements, together with possible matrix effects as a result of the very light mass of peat. A few XRF devices have been especially optimised for peat samples (e.g. 
Cheburkin and Shotyk, 1996; Cheburkin and Shotyk, 2005). When dealing with trace elements, and also to avoid matrix effects, the most widely used technique is ICP-MS. These instruments allow for the measurement of very low concentrations, down to $\mu \mathrm{g} \mathrm{kg}^{-1}$ for ICP-MS and $\mathrm{ng} \mathrm{kg}^{-1}$ or sometimes lower for HR-ICP-MS (e.g. Krachler, 2007 and references therein). Both techniques have been used widely for peat geochemistry (e.g. Rausch et al., 2005; Gonzales et al., 2006; Cloy et al., 2008). Other techniques have been used, such as inductively coupled plasma optical emission spectroscopy (ICP-OES, e.g. Yafa et al., 2004; Mighall et al., 2009), or scanning electron microscope equipped with an energy dispersive XRF analyser (SEM-EDX) for specific purposes (Rausch et al., 2005; De Vleeschouwer et al., 2008), such as mineral identification. Scanning XRF has also been used on peat cores (Lowe et al., 1981; Gehrels et al., 2008; De Vleeschouwer et al., 2008); it gives promising results but is limited by the problem of surface roughness and the pore spaces in peat cores, because these can generate high signal noise.

Mass spectrometry, either thermal ionisation mass spectrometry or ICP-MS (possibly with multi-collectors), can also be used for the determination of the isotopic composition of peat samples. It has been used commonly for lead isotopes (Shotyk et al., 1998; Le Roux et al., 2005; Kylander et al., 2005) and also for Sr after mineral extraction (Sapkota, 2006) and Nd isotopes on a swamp core (Kamenov et al., 2009).

\subsection{Identification of events}

Elemental concentration profiles are rarely used for palaeoclimatic reconstruction in peat, because the elemental concentration is influenced by the peat accumulation rate. Elemental ratios are therefore preferred to identify key intervals, such as the Younger Dryas (YD), for which there is large variability in dust composition (Shotyk et al., 2001). Most often, elemental ratios are constructed using a "conservative element"-such as titanium (Ti), zirconium ( $\mathrm{Zr}$ ) or scandium ( $\mathrm{Sc}$ ). Titanium and $\mathrm{Zr}$ have been chosen because they are located in accessory mineral phases (e.g. titanite, ilmenite for $\mathrm{Ti}$ and zircon for $\mathrm{Zr}$ ) and not sensitive to weathering. Therefore, these elements are not subject to chemical and/or physical fractionation linked to soil erosion. Scandium has advantages, because it has no preferential mineral phase and also because its release caused by anthropogenic activities is negligible, as the world production of Sc remains low (ca. $\left.4 \mathrm{t}^{-1}\right)$.

Conservative elements in ombrotrophic peat can also be used to reconstruct atmospheric dust fluxes. By knowing the concentration of the conservative element in the peat and in the source, it is possible to estimate the amount of dust particles eroded from this source. The calculation is made in two steps. The first is to obtain the soil dust concentration in the studied profile by dividing the conservative element concentration by its counterpart in the Earth's Upper Continental Crust (UCC) or in the local background. The second is to reconstruct the atmospheric soil dust flux (ASD). As with elemental concentration, soil dust concentration may be affected by changes in accumulation rates. Therefore, the ASD can be calculated by multiplying the dust concentration by the bulk density and the mean accumulation rate derived from ${ }^{14} \mathrm{C}$ and ${ }^{210} \mathrm{~Pb}$ ages (e.g. Shotyk et al., 2002). It could be assumed that natural soil dust is derived from a source with a composition close to published UCC (e.g. Taylor and McLennan, 1985; Wedepohl, 1995). However, the local soil dust may be geochemically very different from the UCC, so both local and regional background geochemistry should be assessed. The local background can be characterised using the deepest layers of the peat core, most often corresponding to minerotrophic layers or pre-bog lake sediments influenced by local soil erosion. The regional (i.e. long-range) background can be estimated using time intervals where local inputs were at their minimum because of non-human perturbation and maximum vegetation cover, such as Shotyk et al. (2002) use of the early-mid Holocene climatic optimum in the Swiss Jura.

\subsection{Sourcing}

Chemical elements may originate from various sources, generally divided into two categories: natural and anthropogenic. The latter is not considered here. Natural sources of elements can be multiple (Fig. 4), mainly originating from the hydrosphere or the geosphere. Bromine and chlorine have been found in high amounts in oceanic mires (Shotyk et al., 2002; De Vleeschouwer et al., 2009); however, these elements, which are highly enriched in sea salt sprays, are generally poorly retained by peat (Shotyk et al., 2002), although Biester et al. (2004) demonstrated a close relationship between organohalogen concentrations and peat decomposition, a process strongly influenced by climate. Martínez-Cortizas et al. (2007) showed a similar pattern with other major and trace elements. Recently, Schofield et al. (2010) used $\mathrm{Br}$ and $\mathrm{Cl}$ as a proxy for storminess in their study of southern Greenland. Other studies have shown that silicon, aluminium, titanium and zirconium, together with rare earth elements (REE) are valuable tracers of soil dust inputs (e.g. Hölzer and Hölzer, 1998; Shotyk et al., 2001). Lead and lead isotopes have been used to trace variation in atmospheric dust composition (e.g. Kylander et al., 2010). Volcanic events can also be determined by their non-specific elemental distribution, especially for REE (e.g. Shotyk et al., 2001; Weiss et al., 2002; Kylander et al., 2007; Kylander and Muller, 2007 and references therein) but also for Hg (Roos-Barraclough et al., 2002).

\subsection{Applications and examples}

\subsubsection{Reconstruction of dust flux}

Previous work showed that ASD flux variability is linked to Younger Dryas climatic events (e.g. Shotyk et al., 1998), and this formed the basis for ASD reconstruction, encouraging scientists to investigate Holocene time intervals in mires. However, even now, only a few ASD curves have been generated from mires at highresolution, because (i) ASD peaks generally occur during shortterm intervals (at least in Northern Europe), in which very few samples are analysed; (ii) many radiocarbon dates are needed for precise and accurate dating; and (iii) ASD is still an indirect parameter that needs to be cross-checked with the direct quantification of mineral matter in the peat. Recent work has focused on high-resolution reconstruction of dust content in the late Holocene, on the South Swedish (de Jong et al., 2007) and North Polish coasts (De Vleeschouwer et al., 2009). The Scandinavian records were not

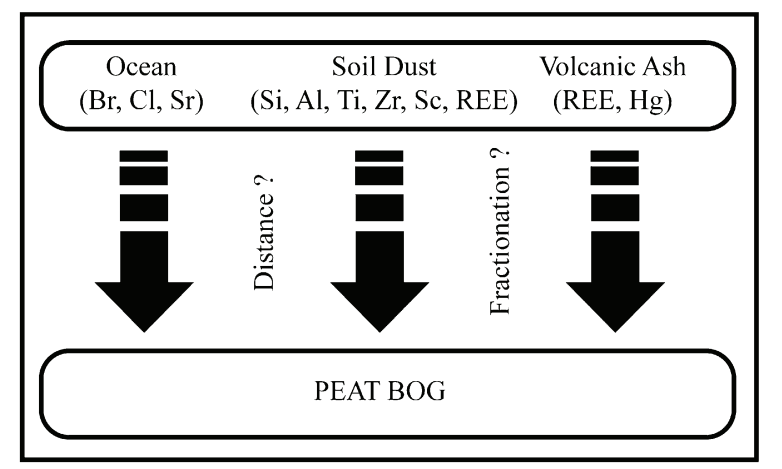

Fig. 4. Chemical elements found in a peat bog originating mainly from natural sources. 
acquired through geochemistry, but rather through the counting of mineral particles in the peat records; while in Poland, a highresolution geochemical study of an ombrotrophic mire allowed for the reconstruction of ASD using titanium as a conservative element. Both records were recently compared in De Vleeschouwer et al. (2009) and de Jong et al. (2010) and gave promising results, showing similarities in signals, in particular during the Little Ice Age (LIA) where enhanced ASD was recorded, suggesting increased erosion and wind storminess. However, considerable effort has to be devoted to assess enhanced ASD accurately during cold phases, especially because coastal areas are rich in easily erodible sand and finer material. Continental sites may not permit mineral counting, but only ASD reconstruction through elemental geochemistry.

\subsubsection{Desert dust fluxes and signatures}

The principal natural global dust sources are deserts, and before agriculture and metallurgy, long-distance desert-dust transport and its deposition was often the predominant mineral source in peatlands.

The Sahara was recognized as a predominant source of dust in European mires, using Pb isotopes (Shotyk et al., 1998, 2001). Lead isotope signatures from two mires (Swiss Jura: Shotyk et al., 1998, 2001; and Galicia: Martinez-Cortizas et al., 2002; Kylander et al., 2005) are compared for the early Holocene in Fig. 5. The two sites have different background local isotope signatures. However, the influence of Saharan dust is possibly marked in both sites by a general trend towards less radiogenic values during the midHolocene. This corresponds to instability and aridification of the Sahara c. 6000-4000 cal. BP (Renssen et al., 2006). The Swiss core records a longer time interval, showing the influence of Sahara dust around $8000 \mathrm{cal} \mathrm{yr} \mathrm{BP}$ and an isotopic shift attributable to deposition of the Vasset-Killian Tephra layer. Recent work by Kylander et al. (2010) summarises pre-anthropogenic Pb isotope chronologies obtained using peat and ice archives in both hemispheres and tries to distinguish similar trends and specific events like volcanic eruptions. It also emphasises that more work is needed to clarify the influence of local and regional dust inputs versus long-range transported particles.

In New Zealand, Marx et al. (2009) reported rates of Australian dust deposition over the last $c .8000$ years using records extracted from an ombrotrophic mire. The trace element chemistry, principally light REE, of deposited dust is used to identify the Australian

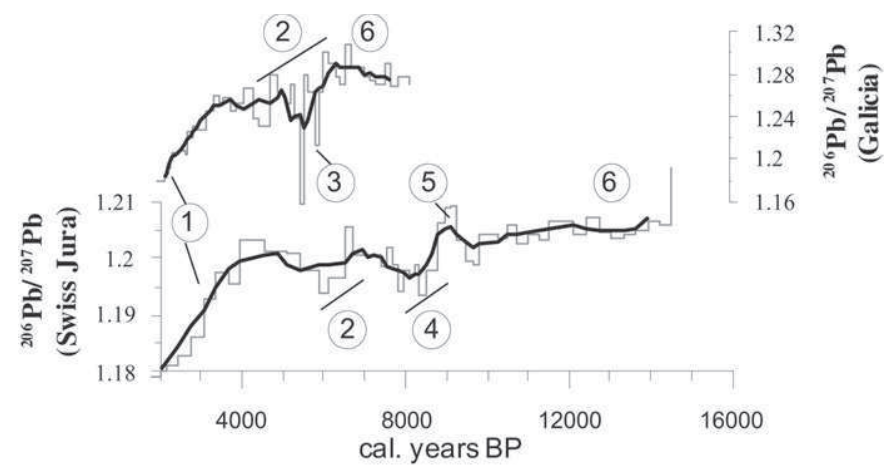

Fig. 5. Comparison of the early to middle Holocene ${ }^{206} \mathrm{~Pb} /{ }^{207} \mathrm{~Pb}$ signature in two ombrotrophic peat bogs from Swiss Jura (Shotyk et al., 1998, 2001) and Galicia (Martinez-Cortizas et al., 2002; Kylander et al., 2005). Dark lines: 4-sample running average. 1. Beginning of the metallurgy and dispersion of anthropogenic lead. 2 . Instability and aridification of Sahara and/or long-range transport of volcanic particles (Kylander et al., 2010). 3. Unknown punctual events (Kylander et al., 2005)-most probably distinct large Icelandic eruptions (Kylander et al., 2010). 4. Sahara influence around 8000 cal. BP. 5. Vasset-Killian Eruption. 6. Minerotrophic peat layers: local background. source areas, and to calculate Australian dust deposition rates in New Zealand. In this area, the relative contribution of Australian dust varies between 30 and 90\%. Marx et al. (2009) identified a four-fold increase in dust flux strength and a change in source occurring after 4800 cal. BP, with central Australian dust source regions, such as the Lake Eyre Basin, becoming active.

Early geochemical studies (e.g. Rauch et al., 2004) revealed promising results. Expanding the number of sites and area, and combining different geochemical proxies (Shotyk et al., 2005; Kamenov et al., 2009; Sapkota, 2006) including trace elements, $\mathrm{Hg}$, and isotopes of $\mathrm{Pb}, \mathrm{Nd}$ and $\mathrm{Sr}$, will increase the number of proxies, which will help to discriminate between the different possible dust sources during the Holocene.

\section{Conclusions and perspectives}

A relationship between peat growth and climate change has been established, although there remain misgivings amongst some researchers in eastern Fennoscandia, related to long-held views on autogenic succession in mires. Quantifying that relationship has proved more problematic, and relating the biological proxy data directly to climate parameters is also difficult. Recent work also shows promising results in the reconstruction of local and regional climate variability using inorganic geochemistry in peat bogs. However, it should be emphasized that no direct climatic parameter is derived using geochemical records, but reconstructed dust fluxes and their sourcing can give information about local and/or regional climatic instabilities during a particular period of time. Table 1 lists several techniques that may be able to generate further proxy-climate indicators from peats. These include new geochemical signatures (e.g. the application of non-traditional isotopes to dust sourcing) and new biomarkers (glycerol dialkyl glycerol tetraethers; isoprenoids, derived from Archaea) in addition to attempting to define species-specific, compound-specific stable-isotope signatures.

For proxy-climate research from mires, the selection of site is crucial (De Vleeschouwer et al., 2010b), followed by high-resolution sampling and the provision of a detailed chronology. Laboratory protocols for a range of techniques have been published recently for researchers (see De Vleeschouwer et al., 2010a). However, whilst it is desirable to follow these explicitly for mires that are ombrotrophic, it must be recognised that not all proxies and techniques have universal applicability, owing to differences in mire-species assemblages, mire formation, topographic controls, and geochemical characteristics.

Recent works show that the combination of inorganic geochemical proxies together with mineralogical and biological proxies are key to a better understanding of the causes and consequences of short-term climatic events in the Holocene. Peat bogs are therefore an ideal Holocene archive to work with, as they display high preservation capacities, not just of biological proxies but also of small inorganic particles.

\section{Acknowledgements}

This paper arose from discussions at a Workshop, entitled Peatland Archives of Holocene Climate Variability, held at Vihula Manor, Estonia, May 2009, funded by the US National Science Foundation, the UK Quaternary Research Association and facilitated by the University of Tartu. A. Martinez-Cortizas, M. Kylander and W. Shotyk provided $\mathrm{Pb}$ isotope data and allowed their use in Fig. 5.

\section{References}

Aaby, B., 1976. Cyclic climatic variations in climate over the past 5500 years reflected in raised bogs. Nature 263, 281-284. 
Aaby, B., Tauber, H., 1975. Rates of peat formation in relation to degree of humification and local environment, as shown by studies of a raised bog in Denmark. Boreas 4, 1-14.

Avsejs, L.A., Nott, C.J., Xie, S., Maddy, D., Chambers, F.M., Evershed, R.P., 2002. 5-nAlkylresorcinols as biomarkers of sedges in an ombrotrophic peat section. Organic Geochemistry 33, 861-867.

Baas, M., Pancost, R., van Geel, B., Sinninghe Damsté, J.S., 2000. A comparative study of lipids in Sphagnum species. Organic Geochemistry 31, 535-541.

Backéus, I., 1990. The cyclic regeneration on bogs-a hypothesis that became an established truth. Striae 31, 33-35.

Barber, K.E., 1981. Peat Stratigraphy and Climatic Change-a Palaeoecological Test of the Theory of Cyclic Peat Bog Regeneration. A. A. Balkema, Rotterdam.

Barber, K.E., 2006. Peatland records of Holocene climate change. In: Elias, S.A. (Ed.), Encyclopedia of Quaternary Science. Elsevier, Oxford, pp. 1884-1895.

Barber, K.E., Langdon, P.G., 2007. What drives the peat-based palaeoclimate record? A critical test using multi-proxy climate records from northern Britain. Quaternary Science Reviews 26, 3318-3327.

Barber, K.E., Chambers, F.M., Maddy, D., Stoneman, R., Brew, J., 1994. A sensitive high-resolution record of late-Holocene climatic change from a raised bog in northern England. The Holocene 4, 200-207.

Beer, J., van Geel, B., 2008. Holocene climate change and the evidence for solar and other forcings. In: Battarbee, R.W., Binney, H.A. (Eds.), Natural Climate Variability and Global Warming: A Holocene Perspective. Wiley-Blackwell, Chichester, pp. 138-162.

Belyea, L.R., Clymo, R.S., 2001. Feedback control of the rate of peat formation. In: Proceedings of the Royal Society of London: Biological Sciences, 268, pp. 1315-1321.

Biester, H., Keppler, F., Putschew, A., Martinez-Cortizas, A., Petri, M., 2004. Halogen retention, organohalogens, and the role of organic matter decomposition on halogen enrichment in two Chilean peat bogs. Environmental Science Technology 38, 1984-1991.

Bindler, R., 2006. Mired in the past-looking to the future: geochemistry of peat and the analysis of past environmental changes. Global and Planetary Change 53, 209-221.

Bingham, E.M., McClymont, E.L., Väliranta, M., Mauquoy, D., Roberts, Z. Chambers, F.M., Pancost, R.D., Evershed, R.P., 2010. Conservative composition of n-alkane biomarkers in Sphagnum species: implications for palaeoclimate reconstruction in ombrotrophic peat bogs. Organic Geochemistry 41, 214-220.

Björck, S., Clemmensen, L., 2004. Aeolian sediments in raised bog deposits, Halland, SW Sweden: a new proxy record of Holocene winter storminess variation in Southern Scandinavia. The Holocene 14, 677-688.

Blaauw, M., Heuvelink, G.B.M., Mauquoy, D., van der Plicht, J., van Geel, B., 2003. A numerical approach to C-14 wiggle-match dating of organic deposits: best fits and confidence intervals. Quaternary Science Reviews 22, 1485-1500.

Blackford, J.J., Chambers, F.M., 1993. Determining the degree of peat decomposition for peat-based palaeoclimatic studies. International Peat Journal 5, 7-24.

Blytt, A.G., 1876. Essay on the Immigration of the Norwegian Flora during Alternating Rainy and Dry Periods. Cammermayer, Kristiana.

Blytt, A.G., 1882. Die theorie der wechselnden kontinentalen und insularen klimate. Botanische Jahrbücher für Systematik. Pflanzengeschichte und Pflanzengeographie $2,1-50$.

Booth, R.K., 2008. Testate amoebae as proxies for mean annual water-table depth in Sphagnum-dominated peatlands of North America. Journal of Quaternary Science 23, 43-57.

Booth, R.K., 2010. Testing the climate sensitivity of peat-based paleoclimate reconstructions in mid-continental North America. Quaternary Science Reviews 29, 720-731.

Booth, R.K., Meyers, B., 2010. Environmental controls on pore number in Hyalosphenia papilio: implications for paleoenvironmental reconstruction. Acta Protozoologica $49,29-35$

Booth, R.K., Notaro, M., Jackson, S.T., Kutzbach, J.E., 2006. Widespread drought episodes in the western Great Lakes region during the past 2000 years: geographic extent and potential mechanisms. Earth and Planetary Science Letters 242, 415-427.

Booth, R.K., Lamentowicz, M., Charman, D., 2010. Preparation and analysis of testate amoebae in peatland paleoenvironmental studies. Mires and Peat 7,1-7. article 02.

Bradley, R.S., 1999. Paleoclimatology, Reconstructing Climates of the Quaternary, second ed. Harcourt Academic Press, San Diego.

Brenninkmeijer, C.A.M. van Geel, B., Mook, W.G., 1982. Variations in the D/H and ${ }^{18} \mathrm{O} /{ }^{16} \mathrm{O}$ ratios in cellulose extracted from a peat core. Earth and Planetary Science Letters 61, 283-290.

Caseldine, C., Baker, A., Charman, D., Hendon, D., 2000. A comparative study of optical properties of $\mathrm{NaOH}$ peat extracts: implications for humification studies. The Holocene 10, 649-658.

Chambers, F.M., Charman, D.J., 2004. Holocene environmental change: contributions from the peatland archive. The Holocene 14, 1-6.

Chambers, F.M., Barber, K.E., Maddy, D., Brew, J., 1997. A 5500-year proxy-climate and vegetational record from blanket mire at Talla Moss, Peebleshire, Scotland. The Holocene 7, 391-399.

Chambers, F.M., Mauquoy, D., Todd, P.A., 1999. Recent rise to dominance of Molinia caerulea in environmentally sensitive areas: new perspectives from palaeoecological data. Journal of Applied Ecology 26, 719-733.

Chambers, F.M., Mauquoy, D., Brain, S.A., Blaauw, M., Daniell, J.R.G., 2007a. Globally synchronous climate change 2800 years ago: proxy data from peat in South America. Earth and Planetary Science Letters 253, 439-444.
Chambers, F.M., Mauquoy, D., Gent, A., Pearson, F., Daniell, J.R.G., Jones, P.S., 2007b. Palaeoecology of degraded blanket mire in South Wales: data to inform conservation management. Biological Conservation 137, 197-209.

Chambers, F.M., Mauquoy, D., Cloutman, E.W., Daniell, J.R.G., Jones, P.S., 2007c Recent vegetation history of Drygarn Fawr (Elenydd SSSI), Cambrian Mountains, Wales: implications for conservation management of degraded blanket mires. Biodiversity and Conservation 16, 2821-2846.

Chambers, F.M., Daniell, J.R.G., ACCROTELM Members, 2010. Peatland archives of late-Holocene climate change in northern Europe. PAGES News 18 (1), $4-6$.

Chambers, F. M., Beilman, D.W., Yu, Z., 2010/11. Methods for quantifying peat humification, bulk density, organic matter, and carbon for palaeostudies of peatland hydroclimatology and carbon dynamics. Mires and Peat 7, article 07, $1-10$.

Chambers, F.M., Reconstructing and inferring past environmental change. In: Matthews, J.A., Bartlein, P.J., Briffa, K.R., Dawson, A.G., de Vernal, A., Denham, T., Fritz, S.C., Oldfield, F. (Eds) The SAGE Handbook of Environmental Change. SAGE, London, in press.

Charman, D.J., 2001. Biostratigraphic and palaeoenvironmental applications of testate amoebae. Quaternary Science Reviews 20, 1753-1764.

Charman, D.J., 2007. Summer water deficit variability controls on peatland watertable changes: implications for Holocene palaeoclimate reconstructions. The Holocene 17, 217-227.

Charman, D.J., Hendon, D., Woodland, W.A., 2000. The Identification of Testate Amoebae (Protozoa: Rhizopoda) in Peats. Technical Guide No. 9. Quaternary Research Association, London.

Charman, D.J., Blundell, A., ACCROTELM Members, 2007. A new European testate amoebae transfer function for palaeohydrological reconstruction on ombrotrophic peatlands. Journal of Quaternary Science 22, 209-221.

Charman, D.J., Barber, K.E., Blaauw, M., Langdon, P.G., Mauquoy, D., Daley, T.J., Hughes, P.D.M., Karofeld, E., 2009. Climate drivers for peatland palaeoclimate records. Quaternary Science Reviews 28, 1811-1819.

Cheburkin, A.K., Shotyk, W., 1996. An energy-dispersive miniprobe multielement analyser (EMMA) for direct analyses of $\mathrm{Pb}$ and other trace elements in peats. Fresenius Journal of Analytical Chemistry 354, 688-691.

Cheburkin, A.K., Shotyk, W., 2005. Energy-dispersive XRF spectrometer for Ti determination (TITAN). X-Ray Spectrometry 34, 69-72.

Cloy, J., Farmer, J.G., Graham, M.C., Mackenzie, A.B., Cook, G.T., 2008. Historical records of atmospheric Pb deposition in four Scottish ombrotrophic peat bogs: an isotopic comparison with other records from western Europe and Greenland. Global Biogeochemical Cycles 22, 1-16.

Daley, T.J., Barber, K.E., Street-Perrott, F.A., Loader, N.J., Marshall, J.D., Crowley, S.F. Fisher, E.H., 2009. Holocene climate variability revealed by oxygen isotope analysis of Sphagnum cellulose from Walton Moss, northern England. Quaternary Science Reviews 29, 1590-1601.

de Jong, R., Björck, S., Björkman, L., Clemmensen, L.B., 2006. Storminess variation during the last 6500 years as reconstructed from an ombrotrophic peat bog in Halland, southwest Sweden. Journal of Quaternary Science 21, 905-919.

de Jong, R., Schoning, K., Björck, S., 2007. Increased Aeolian activity during climatic regime shifts as recorded in a raised bog in south-west Sweden during the past 1700 years. Climate of the Past Discussions 3, 383-408.

de Jong, R., Blaauw, M., Chambers, F.M., Christensen, T.R., De Vleeschouwer, F., Finsinger, W., Fronzek, S., Johansson, M., Kokfelt, U., Lamentowicz, M., Le Roux, G., Mauquoy, D., Mitchell, E.A.D., Nichols, J.E., Samaritani, E., van Geel, B. 2010. Peatlands and climate. In: Dodson, J. (Ed.), Changing Climates, Earth Systems and Society. Springer-Verlag, Dordrecht, pp. 85-121.

De Vleeschouwer, F., van Vliët-Lanoë, B., Fagel, N., Richter, T., Boës, X., 2008 Development and application of high-resolution petrography on resinimpregnated Holocene peat columns to detect and analyse tephras, cryptotephras, and other materials. Quaternary International 178, 54-67.

De Vleeschouwer, F., Cheburkin, A., Le Roux, G., Piotrowska, N., Sikorski, J., Lamentowicz, M., Fagel, N., Mauquoy, M., 2009. Multiproxy evidences of Little Ice Age palaeoenvironmental changes in a peat bog from northern Poland. The Holocene 19, 625-637.

De Vleeschouwer, F., Hughes, P.D.M., Nichols, J.E., Chambers, F.M. (Eds.), 2010a Special Volume: a Review of Protocols in Peat Palaeoenvironmental Studies. Mires and Peat, 7, p. 1. article 00.

De Vleeschouwer, F., Chambers, F.M., Swindles, G.T., 2010b. Coring and subsampling of peatlands for palaeoenvironmental research. Mires and Peat 7 , $1-10$. article 01.

Denton, G.H., Karlén, W., 1973. Holocene climatic variations-their pattern and possible cause. Quaternary Research 3, 155-205.

Dupont, L.M., Brenninkmeijer, C.A.M., 1984. Palaeobotanic and isotopic analysis of late subboreal and early subatlantic peat from Engbertsdijkveen VII, the Netherlands. Review of Palaeobotany \& Palynology 41, 241-271.

Gehrels, M., Newnham, R.M., Lowe, D.J., Wynne, S., Caseldine, C., 2008. Potential methods for developing a rapid assay of cryptotephra in peat cores. Quaternary nternational 178, 68-84.

Givelet, N., Le Roux, G., Cheburkin, A., Chen, B., Frank, J., Goodsite, M.E., Kempter, H., Krachler, M., Noernberg, T., Rausch, N., Rheinberger, S., Roos-Barraclough, F., Sapkota, A., Scholz, C., Shotyk, W., 2004. Suggested protocol for collecting, handling and preparing peat cores and peat samples for physical, chemical, mineralogical and isotopic analyse. Journal of Environmental Monitoring 6 , 481-492. 
Gonzales, Z.I., Krachler, M., Cheburkin, A.K., Shotyk, W., 2006. Spatial distribution of natural enrichments of As, Se, and U in a minerotrophic Peatland, Gola di Lago, Canton Ticino, Switzerland. Environmental Science and Technology 40, 6568-6574.

Goudie, A.S., Middleton, N.J., 2001. Saharan dust storms: nature and consequences. Earth Science Reviews 56, 179-204.

Granlund, E., 1932. De svenska högmossarnas geologi. Sveriges Geologiska Undersökningar C 373. Årsbog 26, 1-193.

Grosse-Brauckmann, G., 1972a. ãber pflanzliche Makrofossilien mitteleuropâischer-Torfe I. Gewebereste krautiger Pflanzen und ihre Merkmale. Telma $2,19-55$.

Grosse-Brauckmann, G., 1972b. Über pflanzliche Makrofossilien mitteleuropäischer-Torfe II. Weitere Reste (Früchte und Samen, Moose, UA.) und ihre Bestimmungsmöglichkeiten. Telma 4, 51-177.

Grosse-Brauckmann, G., Streitz, B., 1992. Über pflanzliche Makrofossilien mitteleuropäischer-Torfe III. Früchte, Samen und einige Gewebe (Fotos von fossilen Pflanzenresten). Telma 22, 53-102.

Hölzer, A., Hölzer, A., 1998. Silicon and titanium in peat profiles as indicators of human impacts. The Holocene 8, 685-696.

Harrison, S.P., Kohfeld, K.E., Roelandt, C., Claquin, T., 2001. The role of dust in climate changes today, at the last glacial maximum and in the future. Earth Science Reviews 54, 43-80.

Heijmans, M.M.P.D., Mauquoy, D., van Geel, B., Berendse, F., 2008. Long-term effects of climate change on vegetation and carbon dynamics in peat bogs. Journal of Vegetation Science 19, 307-320.

Hendon, D., Charman, D.J., Kent, M., 2001. Palaeohydrological records derived from testate amoebae analysis from peatlands in northern England: within-site variability, between-site comparability and palaeoclimatic implications. The Holocene 11, 127-148.

Hong, Y.T., Jiang, H.B., Liu, T.S., Zhou, L.P., Beer, J., Li, H.D., Leng, X.T., Hong, B., Oin, X.G., 2000. Response of climate to solar forcing recorded in a 6000-year $\delta^{18} \mathrm{O}$ time-series of Chinese peat cellulose. The Holocene 10,1-7.

Hong, Y.T., Wang, Z.G., Jiang, H.B., Lin, Q.H., Hong, B., Zhu, Y.X., Wang, Y., Xu, L.S., Leng, X.T., Li, H.D., 2001. A 6000 -year record of changes in drought and precipitation in northeastern China based on a $\delta^{13} \mathrm{C}$ time series from peat cellulose. Earth and Planetary Science Letters 185, 111-119.

Hou, J., Huang, Y., Oswald, W., Foster, D.R., Shuman, B., 2007. Centennial-scale compound-specific hydrogen isotope record of Pleistocene-Holocene climate transition from southern New England. Geophysical Research Letters 34, L19706.

Hughes, P.D.M., Barber, K.E., 2004. Contrasting pathways to ombrotrophy in three raised bogs from Ireland and Cumbria, England. The Holocene 14, 65-77.

Hughes, P.D.M., Blundell, A., Charman, D.J., Bartlett, S., Daniell, J.R.G., Wojatschke, A., Chambers, F.M., 2006. An 8,500 cal. year multi-proxy climate record from a bog in eastern Newfoundland: contributions of meltwater discharge and solar forcing. Quaternary Science Reviews 25, 1208-1227.

Jung, W., 1936. Thekamöben eines Eggegebirgsmoores und zweier Moore im Hohen Venn. Annales de Protistologie V, 83-123.

Kamenov, G.D., Brenner, M., Tucker, J.L., 2009. Anthropogenic versus natural control on trace element and $\mathrm{Sr}-\mathrm{Nd}-\mathrm{Pb}$ isotope stratigraphy in peat sediments of southeast Florida (USA), $\sim 1500$ AD to present. Geochimica et Cosmochimica Acta 73, 3549-3567.

Katz, N.J., Katz, S.V., Skobeyeva, E.I., 1977. Atlas of Plant Remains in Peat Soil. Nedra, Moscow.

Kilian, M.R., van der Plicht, J., van Geel, B., 1995. Dating raised bogs: new aspects of AMS ${ }^{14} \mathrm{C}$ wiggle matching, a reservoir effect and climatic change. Quaternary Science Reviews 14, 959-966.

Kilian, M.R., van Geel, B., van der Plicht, J., 2000. ${ }^{14} \mathrm{C}$ AMS wiggle matching of raised bog deposits and models of peat accumulation. Quaternary Science Reviews 19, 1011-1033.

Krachler, M., 2007. Environmental applications of single collector high resolution ICP-MS. Journal of Environmental Monitoring 9, 790-804.

Kylander, M.E., Muller, J., 2007. Inorganic geochemistry in paleoclimate: tools and trends in the analysis of peat and lake sediments. In: Peretz, L.N. (Ed.), Climate Change Research Progress. Nova Science Publishers, New York, pp. 155-180.

Kylander, M.E., Weiss, D.J., Martínez-Cortizas, A., Spiro, B., García-Sánchez, R., Coles, B.J. 2005. Refining the pre-industrial atmospheric $\mathrm{Pb}$ isotope evolution curve in Europe using an 8000-year old peat core from NW Spain. Earth and Planetary Science Letters 240, 467-485.

Kylander, M.E., Muller, J., Wüst, R.A.J., Gallagher, K., Garcia-Sanchez, R., Coles, B.J., Weiss, D.J., 2007. Rare earth element and $\mathrm{Pb}$ isotope variations in a $52 \mathrm{kyr}$ peat core from Lynch's Crater (NE Queensland, Australia): proxy development and application to paleoclimate in the southern Hemisphere. Geochimica et Cosmochimica Acta 71, 942-960.

Kylander, M.E., Klaminder, J., Bindler, R., Weiss, D.J., 2010. Natural lead isotope variations in the atmosphere. Earth and Planetary Science Letters 290, 44-53.

Lamentowicz, M., Mitchell, E.A.D., 2005. The ecology of testate amoebae (protists) in Sphagnum in north-western Poland in relation to peatland ecology. Microbial Ecology 50, 48-63.

Lamentowicz, Ł, Lamentowicz, M., Gąbka, M., 2008. Testate amoebae ecology and a local transfer function from a peatland in western Poland. Wetlands 28 , $164-175$.
Lamentowicz, M., van der Knaap, W., Leeuwen, J.F.N., Hangartner, S., Mitchell, E.A.D., Goslar, T., Kamenik, C., 2010. A multi-proxy high-resolution approach to reconstructing past environmental change from an Alpine peat archive. PAGES News 18 (1), 13-15.

Le Roux, G., Shotyk, W., 2006. Alteration of minerals in peat bogs. In: Martini, P., Martinez-Cortizas, A. (Eds.), Peatlands: Evolution and Records of Environmental and Climatic Changes. Developments in Earth Surface Processes, Vol. 9. Elsevier, Amsterdam, p. 606

Le Roux, G., Aubert, D., Stille, P., Krachler, M., Kober, B., Cheburkin, A., Bonani, G., Shotyk, W., 2005. Recent atmospheric Pb deposition at a rural site in southern Germany assessed using a peat core and snowpack, and comparison with other archives. Atmospheric Environment 39, 6790-6801.

Leidy, J., 1879. Fresh-water Rhizopods of North America: Report of the United States Geological Survey of the Territories vol. 12

Loisel, J., Garneau, M., Hélie, J.-F., 2010. Sphagnum $\delta^{13} \mathrm{C}$ values as indicators of palaeohydrological changes in a peat bog. The Holocene 20, 285-289.

Lowe, D.J., Hogg, A.G., Hendy, C.H., 1981. Detection of thin tephra deposits in peat and organic lake sediments by rapid X-radiography and X-ray fluorescence techniques. In: Howorth, R., Froggatt, P., Vucetich, C.G., Collen, J.D. (Eds.), Proceedings of Tephra Workshop, 30th June-1st July 1980, Publication of the Geology Department No. 20. Victoria University of Wellington, New Zealand.

Lundqvist, B., 1962. Geological radiocarbon datings from the Stockholm station. Sverige Geoliske Undersökelse C 589, 3-23.

Ménot-Combes, G., Burns, S.J., Leuenberger, M., 2002. Variations of ${ }^{18} \mathrm{O} /{ }^{16} \mathrm{O}$ in plants from temperate peat bogs (Switzerland): implications for paleoclimatic studies. Earth and Planetary Science Letters 202, 419-434.

Magny, M., 2004. Holocene climate variability as reflected by mid-European lakelevel fluctuations and its probable impact on prehistoric human settlements. Quaternary International $113,65-79$

Magny, M., 2007. Lake level studies-West-Central Europe. In: Elias, S. (Ed.), Encyclopedia of Quaternary Studies, Vol. 2. Elsevier, Amsterdam, pp. 1389-1399.

Markel, E., Booth, R.K., Qin, Y., 2010. Testate amoebae and $\delta^{13} \mathrm{C}$ of Sphagnum as surface-moisture proxies in Alaskan peatlands. The Holocene 20, $463-475$.

Martínez Cortizas, A., Pontevedra-Pombal, X., García-Rodeja, E., Nóvoa-Muños, J.C., Shotyk, W., 1999. Mercury in a Spanish peat bog, archive of climate change and atmospheric metal pollution. Science 284, 939-942.

Martínez Cortizas, A., Biester, H., Mighall, T.M., Bindler, R., 2007. Climate-driven enrichment of pollutants in peatlands. Biogeosciences 4, 905-911.

Martinez-Cortizas, A., Garcia-Rodeja, E., Pontevedra-Pombal, X., NóvoaMuños, J.C., Weiss, D., Cheburkin, A., 2002. Atmospheric Pb deposition in Spain during the last 4600 years recorded by two ombrotrophic peat bogs and implications for the use of peat as archive. The Science of the Total Environment 292, 33-44.

Marx, S.M., McGowan, H.A., Kamber, B.S., 2009. Long-range dust transport from eastern Australia: a proxy for Holocene aridity and ENSO-type climate variability. Earth and Planetary Science Letters 282, 167-177.

Mauquoy, D., van Geel, B., 2007. Mire and peat macros. In: Elias, S.A. (Ed.), Encyclopedia of Quaternary Science, Vol. 3. Elsevier, pp. 2315-2336.

Mauquoy, D., van Geel, B., Blaauw, M., van der Plicht, J., 2002. Evidence from northwest European bogs shows "Little Ice Age" climatic changes driven by variations in solar activity. The Holocene $12,1-6$.

Mauquoy, D., Blaauw, M., van Geel, B., Borromei, A., Quattrocchio, M., Chambers, F.M., Possnert, G., 2004a. Late Holocene climatic changes in Tierra del Fuego based on multi-proxy analyses of peat deposits. Quaternary Research 61, 148-158.

Mauquoy, D., van Geel, B., Blaauw, M., Speranza, A., van der Plicht, J., 2004b. Changes in solar activity and Holocene climate shifts derived from ${ }^{14} \mathrm{C}$ wigglematch dated peat deposits. The Holocene 14, 45-52.

Mauquoy, D., Yeloff, D., van Geel, B., Charman, D.J., Blundell, A., 2008. Two decadally resolved records from north-west European peat bogs show rapid climate changes associated with solar variability during the mid-late Holocene. Journal of Quaternary Science 23, 745-763.

Mauquoy, D., Hughes, P.D.M., van Geel, B., 2010/11. A protocol for plant macrofossil analysis of peat deposits. Mires and Peat 7, article 06, 1-5.

Mighall, T.M., Timberlake, S., Foster, I.D.L., Krupp, E., Singh, S., 2009. Ancient copper and lead pollution records from a raised bog complex in Central Wales, UK. Journal of Archaeological Science 36, 1504-1515.

Mitchell, E.A.D., Buttler, A., Warner, B.G., Gobat, J.M., 1999. Ecology of testate amoebae (Protozoa: Rhizopoda) in Sphagnum peatlands in the Jura mountains, Switzerland and France. Ecoscience 6, 565-576.

Mitchell, E.A.D., Charman, D.J., Warner, B.G., 2008a. Testate amoebae analysis in ecological and paleoecological studies of wetlands: past, present and future. Biodiversity and Conservation 17, 2115-2137.

Mitchell, E.A.D., Payne, R.J., Lamentowicz, M., 2008b. Potential implications of differential preservation of testate amoeba shells for paleoenvironmental reconstruction in peatlands. Journal of Paleolimnology 40, 603-618.

Morgan, T.J., Herod, A.A., Brain, S.A., Chambers, F.M., Kandiyoti, R., 2005. Examination of soil contaminated by coal-liquids by size-exclusion chromatography in 1-methyl-2-pyrrolidinone solution to evaluate interference from humic and fulvic acids and extracta from peat. Journal of Chromatography 1095, 81-88.

Muller, J., Kylander, M.E., Wüst, R.A.J., Weiss, D.J., Martinez-Cortizas, A., Le Grande, A.N., Jennerjahn, T., Behling, H., Anderson, W.T., Jacobson, G., 2008. 
Possible evidence for wet Heinrich phases in tropical NE Australia: the Lynch's Crater deposit. Quaternary Science Reviews 27, 468-475.

Nichols, J.E., Huang, Y., 2007. $C_{23}-C_{31}$ n-alkan-2-ones are biomarkers for the genus Sphagnum in freshwater peatlands. Organic Geochemistry 38, 1972-1976.

Nichols, J.E., Booth, R.K., Jackson, S.T., Pendall, E.G., Huang, Y., 2006. Paleohydrologic reconstruction based on n-alkane distributions in ombrotrophic peat. Organic Geochemistry 37, 1505-1513.

Nichols, J.E., Walcott, M., Bradley, R., Pilcher, J., Huang, Y., 2009. Quantification of precipitation seasonality and summer surface wetness using ombrotrophic sediments from an arctic Norwegian peatland. Quaternary Research 72 443-451.

Nichols, JE, Booth, R.K. Jackson, S.T, Pendall, E. , Huang Y, 2010. Differentia hydrogen isotopic ratios of Sphagnum and vascular plant biomarkers in ombrotrophic peatlands as a quantitative proxy for precipitation-evaporation balance. Geochimica et Cosmochimica Acta 74, 1407-1416.

Nilssen, D., Vorren, K.D., 1991. Peat humification and climate history. Norsk Geologisk Tiddskrift 71, 215-217.

Nott, C.J., Xie, S., Avsejs, L.A., Maddy, D., Chambers, F.M., Evershed, R.P., 2000 n-Alkane distribution in ombrotrophic mires as indicators of vegetation change related to climatic variation. Organic Geochemistry 31, 231-235.

Overbeck, F., 1975. Botanisch-geologische Moorkunde. Karl Wachholtz Verlag, Neumünster.

Pancost, R., Baas, M., van Geel, B., Sinninghe Damste, J.S., 2002. Bioarkers as proxies for plant inputs to peats: an example from a sub-boreal ombrotrophic bog. Organic Geochemistry 33, 675-690.

Payne, R.J., Charman, D.J., Mathews, S., Eastwood, W.J., 2008. Testate amoebae as palaeohydrological proxies in Sürmene Ağaçbaşi Yaylasi peatland (Northeast Turkey). Wetlands 28, 311-323.

Payne, R., Lamentowicz, M., Mitchell, E.A.D., in press. Why consistent taxonomy is essential for testate amoeba-based environmental reconstruction. Boreas.

Raghoebarsing, A., Smolders, A., Schmid, M., 2005. Methanotrophic symbionts provide carbon for photosynthesis in peat bogs. Nature 436, 1153-1156.

Rauch, S., Hemond, H.F., Peucker-Ehrenbrink, B., 2004. Source characterisation of atmospheric platinum group element deposition into an ombrotrophic peat bog. Journal of Environmental Monitoring 6, 335-343.

Rausch, N., Ukonmaanaho, L., Nieminen, T.M., Krachler, M., Shotyk, W., 2005. Porewater evidence of metal $(\mathrm{Cu}, \mathrm{Ni}, \mathrm{Co}, \mathrm{Zn}, \mathrm{Cd})$ mobilization in an acidic ombrotrophic bog impacted by a Smelter, Harjavalta, Finland and comparison with reference sites. Environmental Science and Technology 39, 8207-8213.

Renssen, H., Brovkin, V., Fichefet, T., Goosse, H., 2006. Simulation of the Holocen climate evolution in northern Africa: the termination of the African Humid period,. Quaternary International 150, 95-102.

Roos-Barraclough, F., Martinez-Cortizas, A., Garcia-Rodeja, E., Shotyk, W., 2002 A 14,500 year record of the accumulation of atmospheric mercury in peat: volcanic signals, anthropogenic influences, and a correlation to bromine accumulation. Earth and Planetary Science Letters 202, 435-451.

Sachse, D., Radke, J., Gleixner, G., 2006. $\delta$ D Values of individual n-alkanes from terrestrial plants along a climatic gradient-Implications for the sedimentary record. Organic Geochemistry 37, 469-483.

Sannel, A.B.K., Kuhry, P., 2009. Holocene peat growth and decay dynamics in subarctic peat plateaus, west-central Canada. Boreas 38, 13-24.

Sapkota, A., 2006. Mineralogical, chemical, and isotopic ( $\mathrm{Sr}, \mathrm{Pb}$ ) composition of atmospheric mineral dusts in an ombrotrophic peat bog, southern south America. PhD thesis, University of Heidelberg. 162p.

Schofield, J.E., Edwards, K.J. Mighall, T.M. Martínez Cortizas, A Rodríguez Racedo, J., Cook, G., 2010. An integrated geochemical and palynological study of human impacts, soil erosion and storminess from southern Greenland. Palaeogeography, Palaeoclimatology, Palaeoecology 295, 19-30.

Schoning, K. Charman, D.J., Wastegård, S., 2005. Reconstructed water tables from two ombrotrophic mires in eastern central Sweden compared with instrumental meteorological data. The Holocene 15, 111-118.

Seki, O., Meyers, P.A., Kawamura, K., Zheng, Y., Zhou, W., 2009. Hydrogen isotopic ratios of plant wax n-alkanes in a peat bog deposited in northeast China during the last 16 kyr. Organic Geochemistry 40, 671-679.

Sernander, R., 1908. On the evidences of postglacial changes of climate furnished by the peat-mosses of Northern Europe. Geologiska Föreningens Förhandlingar 30 465-473.

Shotyk, W., Weiss, D., Appleby, P.G., Cheburkin, A.K., Frei, R., Gloor, M., Kramers, J.D., Reese, S, van der Knaap, W.O., 1998. History of atmospheric lead deposition since $12,370{ }^{14} \mathrm{C}$ yr BP recorded in a peat bog profile, Jura Mountains, Switzerland. Science 281, 1635-1640.

Shotyk, W., Weiss, D., Kramers, J.D., Frei, R., Cheburkin, A.K., Gloor, M., Reese, S. 2001. Geochemistry of the peat bog at Etang de la Gruère, Jura Mountains, Switzerland, and its record of atmospheric $\mathrm{Pb}$ and lithogenic trace elements (Sc, $\mathrm{Ti}, \mathrm{Y}, \mathrm{Zr}$, Hf and REE) since $12,370{ }^{14} \mathrm{C}$ yr BP. Geochimica et Cosmochimica Acta $65,2337-2360$

Shotyk, W., Krachler, M., Martinez-Cortizas, A., Cheburkin, A.K., Emons, H., 2002. A peat bog record of natural, pre-anthropogenic enrichments of trace elements in atmospheric aerosols since $12.370{ }^{14} \mathrm{C}$ yr BP, and their variation with Holocene climate change. Earth and Planetary Science Letters 199, 21-37.

Shotyk, W., Goodsite, M.E., Roos-Barraclough, F., Givelet, N., Le Roux, G., Weiss, D. Cheburkin, A.K., Knudsen, K., Heinemeier, J., van der Knaap, W.O., Norton, S.A. Lohse, C., 2005. Accumulation rates and predominant atmospheric sources of natural and anthropogenic $\mathrm{Hg}$ and $\mathrm{Pb}$ on the Faroe Islands. Geochimica et Cosmochimica Acta 69, 1-17.

Sillasoo, Ü, Mauquoy, D., Blundell, A., Charman, D., Blaauw, M., Daniell, J.G.R. Toms, P., Newberry, J., Chambers, F.M., Karofeld, E., 2007. Peat multi-proxy data from Männikjärve bog as indicators of Late Holocene climate changes in Estonia. Boreas 36, 20-37.

Skrzypek, G. Kaluzny, A., Wojtun, B., Jedrysek, M-O, 2007. The carbon stable isotopic composition of mosses: a record of temperature variation. Organic Geochemistry 38, 1770-1781.

Smith, A.J.E., 2004. The Moss Flora of Britain and Ireland. Cambridge University Press, Cambridge.

Speranza, A., van Geel, B. van der Plicht, J., 2003. Evidence for solar forcing of climate change at ca. 850 cal BC from a Czech peat sequence. Global and Planetary Change 35, 51-65.

Swindles, G.T., Plunkett, G., Roe, H., 2007. A delayed climatic response to solar forcing at 2800 cal. BP: multi-proxy evidence from three Irish peatlands. The Holocene 17, 177-182.

Swindles, G.T., Charman, D.J., Roe, H.M., Sansum, P.A., 2009. Environmental controls on peatland testate amoebae (Protozoa: rhizopoda) in the North of Ireland: implications for Holocene palaeoclimatic studies. Journal of Paleolimnology 42 $123-140$.

Taylor, S.R., McLennan, S.M., 1985. The Continental Crust: Its Composition and Evolution. Blackwell, Oxford.

Väliranta, M., Korhola, A., Seppä, K., Tuittila, E.-S., Sarmaja-Korjonen, K., Laine, J., Alm, J., 2007. High-resolution reconstruction of wetness dynamics in a southern boreal raised bog, Finland, during the late Holocene: a quantitative approach. The Holocene 17, 1093-1107.

van Geel, B., 1978. A palaeoecological study of holocene peat bog sections in Germany and the Netherlands. Review of Palaeobotany and Palynology 25, $1-120$.

van Geel, B., 1986. Application of fungal and algal remains and other microfossils in palynological analyses. In: Berglund, B.E. (Ed.), Handbook of Holocene Palaeoecology and Palaeohydrology. Wiley, Chichester, pp. 497-505.

van Geel, B., 2001. Non-pollen palynomorphs. In: Smol, J.P., Birks, H.J.B., Last, W.M. Eds.), Tracking Environmental Change Using Lake Sediments. Terrestrial, Algal and Silicaceous Indicators, Vol. 3. Kluwer, Dordrecht, pp. 99-119.

van Geel, B., Aptroot, A., 2006. Fossil ascomycetes in quaternary deposits. Nova Hedwigia 82, 313-329.

van Geel, B., Grenfell, H.R., 1996. Spores of Zygnemataceae (Chapter 7A). In: Jansonius, J., McGregor, D.C. (Eds.), Palynology: Principles and Applications, Vol. 1. American Association of Stratigraphic Palynologists Foundation, pp. 173-179.

van Geel, B., Mook, W.G., 1989. High-resolution ${ }^{14} \mathrm{C}$ dating of organic deposits using natural atmospheric ${ }^{14} \mathrm{C}$ variations. Radiocarbon $31,151-156$.

van Geel, B., Pals, J.P., van Reenen, G.B.A., van Huissteden, J., 1995. The indicator value of fossil fungal remains, illustrated by a palaeoecological record of a Late Eemian/Early Weichselian deposit in the Netherlands. In: Herngreen, G.F.W., van der Valk, L. (Eds.), Neogene and Quaternary Geology of North-West Europe, 52. Mededelingen Rijks Geologische Dienst, pp. 297-315.

van Geel, B., van der Plicht, J., Kilian, M.R., Klaver, E.R., Kouwenberg, J.H.M. Renssen, H., Reynaud-Farrera, I., Waterbolk, H.T., 1998. The sharp rise of $\Delta 14 \mathrm{C}$ ca. 800 cal BC: possible causes, related climatic teleconnections and the impact on human environments. Radiocarbon 40, 535-550.

van Geel, B., Heusser, C.J., Renssen, H., Schuurmans, C.J.E., 2000. Climatic change in Chile at around $2700 \mathrm{BP}$ and global evidence for solar forcing: a hypothesis. The Holocene 10, 659-664.

van Geel, B., Buurman, J., Brinkkemper, O., Schelvis, J., Aptroot, A., van Reenen, G., Hakbijl, T., 2003. Environmental reconstruction of a Roman period settlement site in Uitgeest (The Netherlands), with special reference to coprophilous fungi. Journal of Archaeological Science 30, 873-883.

van der Plicht, J., van Geel, B., Bohncke, S.J.P., Bos, J.A.A., Blaauw, M., Speranza, A.O.M., Muscheler, R., Björck, S., 2004. The Preboreal climate reversal and a subsequent solar-forced climate shift. Journal of Quaternary Science 19 263-269.

Warner, B.G., Asada, T., Quinn, N.P., 2007. Seasonal influences on the ecology of testate amoebae (protozoa) in a small Sphagnum peatland in Southern Ontario Cananda. Microbial Ecology 54, 91-100.

Wedepohl, K.H., 1995. The composition of the continental crust. Geochimica et Cosmochimica Acta 59, 1217-1232.

Weiss, D., Shotyk, W., Rieley, J., Page, S., Gloor, M., Reese, S., Martinez-Cortizas, A. 2002. The geochemistry of major and selected trace elements in a forested peat bog, Kalimantan, SE Asia, and its implications for past atmospheric dust deposition. Geochimica et Cosmochimica Acta 66, 2307-2323.

Williams, T., Flannagan, L., 1996. Effect of changes in water content on photosynthesis, transpiration and discrimination against ${ }^{13} \mathrm{CO}_{2}$ and $\mathrm{C}^{18} \mathrm{O}^{16} \mathrm{O}$ in Pleurozium and Sphagnum. Oecologia 108, 38-46.

Wilmshurst, J.M., McGlone, M.S., Charman, D.J., 2002. Holocene vegetation and climate change in southern New Zealand: linkages between forest composition and quantitative surface moisture reconstructions from an ombrogenous bog. Journal of Quaternary Science 17, 653-666.

Woodland, W.A., Charman, D.J., Sims, P.C., 1998. Quantitative estimates of water tables and soil moisture in Holocene peatlands from testate amoebae. The Holocene 8, 261-273. 
Xu, H., Hong, Y., Lin, Q., Zhu, Y., Hong, B., Jiang, H., 2006. Temperature responses to quasi-100-yr solar variability during the past 6000 years based on $\delta^{18} \mathrm{O}$ of peat cellulose in Hongyuan, eastern Qinghai-Tibet plateau, China. Palaeogeography, Palaeoclimatology, Palaeoecology 230, 155-164.

Yafa, C., Farmer, J.G., Graham, M.C., Bacon, J.R., Barbante, C., Cairns, W.R.L., Bindler, R., Renberg, I., Cheburkin, A., Emons, H., Handley, M.J., Norton, S.A., Krachler, M., Shotyk, W., Li, X.D., Martinez-Cortizas, A., Pulford, I.D., Maclver, V., Schweyer, J., Steinnes, E., Sjobakk, T.E., Weiss, D., Dolgopolova, A., Kylander, M., 2004. Development of an ombrotrophic peat bog (low ash) reference material for the determination of elemental concentrations. Journal of Environmental Monitoring 6, 493-501.
Yeloff, D., Mauquoy, D., 2006. The influence of vegetation composition on peat humification: implications for palaeoclimatic studies. Boreas 35, 662-673.

Yeloff, D., Charman, D., van Geel, B., Mauquoy, D., 2007. Reconstruction of hydrology, vegetation and past climate change in bogs using fungal microfossils. Review of Palaeobotany and Palynology 146, 102-145.

Zhou, W., Xie, S., Meyers, P.A., Zheng, Y., 2005. Reconstruction of late glacial and Holocene climate evolution in southern China from geolipids and pollen in the Dingnan peat sequence. Organic Geochemistry 36, $1272-1284$. 